\title{
Aanvulling arbeidsmarktmodule i-see project : wetenschappelijk onderwijs
}

Citation for published version (APA):

de Grip, A., Heijke, J. A. M., van Dam, J. W., Dekker, R., \& Wieling, M. (1988). Aanvulling

arbeidsmarktmodule $i$-see project : wetenschappelijk onderwijs. Researchcentrum voor Onderwijs en Arbeidsmarkt, Faculteit der Economische Wetenschappen. ROA Reports No. 2 https://doi.org/10.26481/umarep.1988002

Document status and date:

Published: 01/01/1988

DOI:

10.26481/umarep.1988002

Document Version:

Publisher's PDF, also known as Version of record

\section{Please check the document version of this publication:}

- A submitted manuscript is the version of the article upon submission and before peer-review. There can be important differences between the submitted version and the official published version of record.

People interested in the research are advised to contact the author for the final version of the publication, or visit the DOI to the publisher's website.

- The final author version and the galley proof are versions of the publication after peer review.

- The final published version features the final layout of the paper including the volume, issue and page numbers.

Link to publication

\footnotetext{
General rights rights.

- You may freely distribute the URL identifying the publication in the public portal. please follow below link for the End User Agreement:

www.umlib.nl/taverne-license

Take down policy

If you believe that this document breaches copyright please contact us at:

repository@maastrichtuniversity.nl

providing details and we will investigate your claim.
}

Copyright and moral rights for the publications made accessible in the public portal are retained by the authors and/or other copyright owners and it is a condition of accessing publications that users recognise and abide by the legal requirements associated with these

- Users may download and print one copy of any publication from the public portal for the purpose of private study or research.

- You may not further distribute the material or use it for any profit-making activity or commercial gain

If the publication is distributed under the terms of Article $25 \mathrm{fa}$ of the Dutch Copyright Act, indicated by the "Taverne" license above, 
AANVULLING ARBEIDSMARKTMODULE I-SEE PROJECT

-wetenschappelijk onderwijs-

ROA-R-1988/2

A. de Grip

J.A.M. Heijke

J.W. van Dam

R.J.P. Dekker

M.H. Wieling

RESEARCHCENTRUM VOOR ONDERWIJS EN ARBEIDSMARKT

Faculteit der Economische Wetenschappen

Rijksuniversiteit Limburg

Maastricht, juli 1988 
Niets uit deze uitgave mag worden verveelvoudigd en/of openbaar gemaakt door middel van druk, fotocopie, microfilm of op welke andere wijze dan ook, zonder voorafgaande schriftelijke toestemming van het Ministerie van Sociale Zaken en Werkgelegenheid. In geval van overname van het data-materiaal moet telkens als bronvermelding worden vermeld: "Researchcentrum voor Onderwijs en Arbeidsmarkt" of "ROA". 
INHOUDSOPGAVE

Bladzijde

Voorwoord

$1 \quad$ Inleiding

2 Additionele databronnen

2.1 Integratie deelmarktdata

2.2 Afgestudeerden naar beroepsgroep

2.3 Additionele werkloosheidsdata

4

4

5

6

3 Enkele aanpassingen en correcties

8

3.1 Typering perspectieven en uitwijkmogelijkheden

3.2 Correctie prognose theologie

8

$4 \quad$ Periodieke actualisering data

10

\begin{abstract}
Bijlage I : Arbeidsmarktdata studierichtingen
Bijlage II : Arbeidsmarktdata beroepsklassen en enkele specifieke beroepsgroepen

Bijlage III: Overzicht deelmarktstudies

Bijlage IV : Data-file ten behoeve van updating arbeidsmarktinformatie
\end{abstract}


VOORWOORD

Dit rapport doet verslag van de onderzoeksactiviteiten die zijn verricht ter completering van de arbeidsmarktgegevens met betrekking tot het wetenschappelijk onderwijs in het I-SEE informatiesysteem. Het onderzoek is door het Researchcentrum voor Onderwijs en Arbeidsmarkt (ROA) van de Rijksuniversiteit Limburg uitgevoerd in opdracht van het Ministerie van Sociale Zaken en Werkgelegenheid, D.G. Arbeidsvoorziening. Het rapport is een vervolg op de eerder door het ROA uitgebrachte rapporten 'Inventariserend onderzoek arbeidsmarktmodule I-SEE project' (ROA-R-1987/1) en 'De arbeidsmarktperspectieven van studierichtingen in het wetenschappelijk onderwijs 1992' (ROA-R-1987/3).

Het onderzoek warover hier verslag wordt gedaan stond onder leiding van prof. dr. J.A.M. Heijke, direkteur van het ROA. De dagelijkse leiding was in handen van dr. A. de Grip. Verder werkten aan het onderzoek mee drs. J.W. van Dam, drs. R.J.P. Dekker en student-assistente M.H. Wieling. Contactpersoon namens de opdrachtgever was drs. B. van Amstel, projectleider I-SEE. 


\section{INLEIDING}

In dit onderzoeksrapport wordt verslag gedaan van de onderzoeksactiviteiten die zijn ondernomen om de in het vorige ROA-onderzoeksrapport ten behoeve van I-SEE gepresenteerde arbeidsmarktinformatie ${ }^{1}$ te completeren. Daar de term 'completeren' mogelijkerwijs de suggestie wekt dat een definitief en compleet plaatje wordt gegeven van de ideale inhoud van de arbeidsmarktmodule van I-SEE, geven wij er de voorkeur aan te spreken van een 'aanvulling' van de arbeidsmarktmodule. Immers, zoals reeds in ons vorige I-SEE rapport naar voren werd gebracht, is de aard van de informatie die opgeleverd kan worden in belangrijke mate afhankelijk van de beschikbaarheid van statistisch basismateriaal. Momenteel is dit echter nog ontoereikend om het uiteindelijk gewenste complete 'plaatje' te kunnen presenteren.

Hoofdstuk 2 beschrijft de pogingen die zijn gedaan om nieuwe gegevensbronnen aan te boren. Een van de wegen waarlangs is getracht de arbeidsmarktinformatie aan te vullen, is het onderzoeken van de mogelijkheden om meer specifieke gegevens, afkomstig van verenigingen van afgestudeerden e.d., te integreren met de in het vorige rapport opgeleverde data. In paragraaf 2.1 wordt hiervan verslag gedaan. Daarnaast is er gekeken naar de mogelijkheden om de indeling van het aantal werkenden met een bepaalde opleiding naar beroepsklasse verder te verbijzonderen naar beroepsgroep. Bovendien is geprobeerd om meer specifieke informatie te geven over de omvang en aard van de huidige werkloosheid van academici. Paragraaf 2.3 gaat hier nader op in.

Hoofdstuk 3 beschrijft de aanpassingen die zijn aangebracht in de reeds in het vorige onderzoeksrapport gepresenteerde arbeidsmarktinformatie. Het betreft hier enkele aanpassingen in de wijze van presenteren van de informatie. De belangrijkste verandering die wordt voorgesteld heeft betrekking op de uiteindelijke typering van de arbeidsmarktperspectieven van de verschillende studierichtingen. Tevens is ditmaal bij de berekening van de arbeidsmarktperspectieven rekening gehouden met de omvang van de werkloosheid in het basisjaar van de prognose (paragraaf 3.1 ). Ten slotte is

1 A. de Grip, J.A.M. Heijke, R.J.P. Dekker, L.F.M. Groot, L.A. Yos, De arbeidsmarktperspectieven van studierichtingen in het wetenschappelijk onderwijs. Arbeidsmarktmodule I-SEE project, ROA-R-1987/3, Maastricht 1987. 
nog een correctie aangebracht in de berekening van de verwachte vervangingsvraag en de instroom op de arbeidsmarkt van afstuderenden in de studierichting theologie (paragraaf 3.2).

Hoofdstuk 4 gaat in op de noodzaak tot een periodieke actualisering van de arbeidsmarktinformatie. Daarbij zal ook aandacht worden besteed aan de wijze waarop nieuwe data zouden kunnen worden aangeleverd. Ook zal in dit hoofdstuk worden ingegaan op de onderlinge afstemming van de arbeidsmarkt-en beroepenmodule van I-SEE, in het bijzonder op de gehanteerde beroepen- en bedrijfstakkenindelingen en de daaraan gekoppelde benamingen.

Ten einde de 'voorlopig definitieve' arbeidsmarktinformatie met betrekking tot het wetenschappelijk onderwijs in één rapport bij elkaar te houden, zijn in de bijlagen I en II ook de ten opzichte van het vorige onderzoeksrapport niet-aangepaste arbeidsmarktgegevens opgenomen. 


\section{ADDITIONELE DATABRONNEN}

\subsection{Integratie deelmarktdata}

In deze paragraaf zal verslag worden gedaan van de inventarisatie die is verricht van de bestaande deelmarktstudies met betrekking tot het wetenschappelijk onderwijs. Het doel van deze inventarisatie was om additionele databronnen aan te boren, op basis waarvan meer specifieke arbeidsmarktinformatie kan worden gegeven.

Gekeken is naar onderzoeken die kwantitatieve informatie hebben voortgebracht met betrekking tot bepaalde delen van de arbeidsmarkt. Daarbij hebben we ons beperkt tot gegevens over bepaalde categorieën opgeleiden, het beroep dat zij uitoefenen en de bedrijfstak waarin men werkzaam is.

Zo worden er met enige regelmaat loopbaan- en vacature-enquêtes gehouden door beroepsverenigingen als het Nederlands Instituut van Landbouwkundig Ingenieurs (NILI), het Koninklijk Instituut van Ingenieurs (KIVI) en de Koninklijke Nederlandse Chemische Vereniging (KNCV).

Daarnaast zijn er onderzoeken bekend van onderwijsinstellingen (universiteiten, faculteiten) die ófwel continu bijhouden waar hun afgestudeerden komen te werken ófwel eenmalig of periodiek enquêtes (laten) verrichten, met als doel hun onderwijsaanbod te evalueren, c.q. de behoefte aan vervolgonderwijs in kaart te brengen.

$\mathrm{Na}$ een eerste inventarisatie zijn circa 30 publikaties geselecteerd, en doorgenomen op de aanwezigheid van bruikbare kwantitatieve informatie. Bijlage III geeft een overzicht van deze deelmarktstudies in de vorm van een literatuurlijst. Als uitgangspunt voor deze literatuurlijst fungeerde het reeds bestaande 'Overzicht publikaties met betrekking tot bepaalde studierichtingen'2. Deze lijst is enerzijds aangevuld met andere publicaties die kwantitatieve arbeidsmarktinformatie bevatten en anderzijds geschoond van publikaties waarin geen oorspronkelijke kwantitatieve gegevens voorkomen.

2 ROA/I-SEE, oktober 1987. 
Hoewel het verheugend is dat voor een groot aantal studierichtingen artikelen, rapporten, e.d. konden worden gevonden, blijken aan de daarin gepresenteerde gegevens nogal wat beperkingen te kleven, zoals:

- regelmatig gebruik van reeds bekend cijfermateriaal; met name de GABwerkloosheidscijfers;

- definities met betrekking tot werkend/werkloos, die niet sporen met de 'officiële' CBS-definities;

- zeer uiteenlopende, niet tot de CBS-classificaties te herleiden beroepen- en bedrijfstakkenclassificaties;

- niet landelijk representatieve onderzoekspopulaties;

- relatief hoge non-respons;

- niet vergelijkbare vraagstellingen.

Vooralsnog betekent dit dat de hoeveelheid voor de arbeidsmarktmodule van I-SEE geschikte gegevens die afkomstig zijn van deelmarktstudies, zeer beperkt is. Het betreft hier bovendien louter historische data.

Het zou interessant zijn om op basis van de resultaten van dergelijke deelmarktstudies te komen tot een verdere verbijzondering, c.q. een betere afbakening van de arbeidsmarktsegmenten, die zijn onderscheiden bij de voorspellingen van de arbeidsmarktperspectieven van studierichtingen. Dit vereist echter dat de in de deelmarktstudies gehanteerde beroepen- en bedrijfstakkenclassificaties vertaald kunnen worden naar de CBS-classificaties. Een dergelijke vertaalslag is alleen mogelijk wanneer de in een deelstudie gehanteerde classificaties louter een verbijzondering geven van de CBS-categorieën, die voor de desbetreffende studierichting te globaal zijn, en niet, zoals vaak het geval is, verschillende CBS-categorieën overlappen. Met de Stichting Maatschappelijke Plaats Wageningse afgestudeerden (MPW) is onlangs een gesprek gevoerd over de mogelijkheid om te komen tot een aanpassing van de gehanteerde beroepen- en bedrijfstakkenclassificaties. Voor de MPW (NILI)-loopbaanenquête van 1988 bleek een dergelijke aanpassing helaas niet meer te realiseren.

Voor de goede orde moet hierbij wel worden opgemerkt dat meer specifieke prognoses alleen mogelijk zijn, wanneer er sprake is van onderling min of meer afgebakende arbeidsmarktsegmenten. Een nadere verbijzondering binnen bepaalde studierichtingen naar de universiteit waar afgestudeerden zijn opgeleid, moet vanuit dit oogpunt dan ook als irreëel worden beschouwd. 


\subsection{Afgestudeerden naar beroepsgroep}

De historische data van de verschillende studierichtingen zijn tevens aangevuld, door de belangrijkste beroepsklassen waarin men werkzaam is (Bijlage I, ad II), te verbijzonderen naar de belangrijkste beroepsgroepen. Ook hier betreft het gemiddelde percentages over de periode 1979-1985 en zijn alleen de beroepsgroepen vermeld warin minstens $5 \%$ van de desbetreffende categorie afgestudeerden werkzaam is. Dit percentage wordt telkens vermeld, tenzij er minder dan 1000 afgestudeerden in de desbetreffende beroepsgroep werken. In dit laatste geval wordt wel de beroepsgroep genoemd, maar in plaats van een exact percentage, het \# teken afgedrukt.

Evenals bij de beroepsklassen, is ook bij de opgenomen beroepsgroepen aangegeven of er sprake is van een bepaalde trendmatige ontwikkeling. Deze trendindicatoren zijn op identieke wijze berekend en getypeerd als in het vorige rapport ${ }^{3}$.

\subsection{Additionele werkloosheidsdata}

Met behulp van het basisbestand van de geregistreerde werkloosheid van het Ministerie van Sociale Zaken en Werkgelegenheid is geprobeerd het inzicht in de samenstelling van de werkloosheid van de verschillende studierichtingen te vergroten. Het betreft hier een momentopname van de situatie op 1 april 1987.

Voor de 13 clusters van universitaire studierichtingen en de verschillende specifieke studierichtingen daarbinnen, worden de volgende gegevens verstrekt:

- de regionale spreiding van de werkloosheid, te weten de provincies waar de relatieve werkloosheid hoog is (d.w.z. $5 \%$ boven het gemiddelde aandeel van een provincie in de landelijke werkloosheid van academici). Zoals te verwachten viel, is er sprake is van een concentratie van de werkloosheid in de provincies waar de desbetreffende studierichtingen gevolgd kunnen worden;

- het aandeel van de langdurig werklozen (langer dan 1 jaar ingeschreven) in de totale werkloosheid in een studierichting. Dit geeft een indica-

3 De Grip c.s., op cit., p. 9 en bijlage III. 
tie van de mate warin er sprake is van hardnekkige werkloosheid, als het aandeel van de langdurige werkloosheid groot is, of slechts van frictiewerkloosheid, wanneer het aandeel van de langdurige werkloosheid in de totale werkloosheid relatief gering is;

- het aandeel van de afgestudeerden die nog niet eerder hebben gewerkt in de totale werkloosheid van een studierichting. Dit geeft een indicatie van de relatieve omvang van de 'schoolverlaterswerkloosheid'. In het algemeen ligt dit aandeel voor universitaire opgeleiden relatief hoog, hetgeen er op wijst dat het werkloosheidsprobleem op dit arbeidsmarktsegment voor het grootste deel getypeerd kan worden als 'intredewerkloosheid';

- de belangrijkste beroepen van inschrijving naar studierichting. Van iedere studierichting worden de beroepen vermeld, waarvoor minimaal $5 \%$ van de werkloze afgestudeerden in de desbetreffende studierichting staat ingeschreven. In principe zou deze informatie kunnen worden vergeleken met de werkgelegenheid in de belangrijkste beroepsklassen waarin de desbetreffende categorie afgestudeerden werkzaam is. Helaas is de beroepencodering met betrekking tot de werklozen (de ARBI-code) niet direct vertaalbaar naar de CBS-beroepenclassificatie. Momenteel wordt door het Ministerie van Sociale Zaken en Werkgelegenheid gewerkt aan een vertaalsleutel tussen beide classificaties.

Naast de bovenstaande gegevens is ook onderzocht welk deel van de werklozen niet op zoek is naar een full-time baan. Dit percentage varieert voor de verschillende studierichtingen tussen de nul en negen procent. Gezien deze relatief lage percentages en de geringe onderlinge verschillen, lijkt het ons niet zinvol deze informatie in de I-SEE arbeidsmarktmodule op te nemen. Voor de volledigheid vermelden we de percentages hieronder:

Aandeel werklozen op zoek naar een deeltijdfunctie $(\%)$

$\begin{array}{ll} & \% \\ & 9 \\ \text { Letteren } & 9 \\ \text { Theologie } & 8 \\ \text { Agrarische wetenschappen en huishoudkunde } & 4 \\ \text { Wis- en natuurkunde } & 6 \\ \text { Technische wetenschappen } & 4 \\ \text { Medische opleidingen } & 5 \\ \text { Farmacologie } & 0 \\ \text { Economische wetenschappen en bedrijfskunde (drs.) } & 3 \\ \text { Econometrie, actuariaat en bedrijfskunde (ir.) } & 7 \\ \text { Rechten } & 3 \\ \text { Sociaal-culturele wetenschappen } & 6 \\ \text { Kunstonderwijs } & 6\end{array}$




\section{ENKELE AANPASSINGEN EN CORRECTIES}

\subsection{Typering perspectieven en uitwijkmogelijkheden}

Op verzoek van de ISBV-werkgroep automatisering ${ }^{4}$ is ook de omvang van de werkloosheid meegenomen in de arbeidsmarktindicator die een typering geeft van de arbeidsmarktperspectieven van de verschillende studierichtingen. Uitgaande van dezelfde classificatiemaatstaven als in De Grip, Heijke, Dekker, Groot en Vos $(1987$, p. 39) levert dit alleen voor de studierichtingen agrarische wetenschappen en huishoudkunde een andere typering op van de arbeidsmarktperspectieven.

Tevens is de omvang van de werkloosheid in het basisjaar van de prognose opgenomen als een aparte factor in de typering van de arbeidsmarktperspectieven. Daarbij is uitgegaan van de volgende typering van de werkloosheid (W) op basis van een gemiddeld percentage voor academici van $7 \%$.

$$
\begin{aligned}
& W \leq 2 \% \text { erg lage werkloosheid } \\
& 2 \%<W \leq 5 \% \text { lage werkloosheid } \\
& 5 \%<W \leq 9 \% \text { gemiddelde werkloosheid } \\
& 9 \%<W \leq 15 \% \text { hoge werkloosheid } \\
& W>15 \% \text { erg hoge werkloosheid }
\end{aligned}
$$

Deze werkloosheidstypering vormt nu een onderdeel van de meer uitgebreide verbale typering van de arbeidsmarktperspectieven van de verschillende studierichtingen. Op deze manier is getracht de in het vorige rapport ietwat a) te summiere typeringen (goed, redelijk, matig en slecht) nader toe te lichten met een kwalitatieve aanduiding van de achterliggende processen: de werkgelegenheidsgroei, de vervangingsuraag en de instroom van afstuderenden.

Bij de typering van de verschillende beroepsklassen is de term 'arbeidsmarktperspectief' vervangen door 'werkgelegenheidsperspectief'. Dit laatste begrip verdient hier de voorkeur, omdat voor de bepaling van het arbeidsmarktperspectief naast de ontwikkeling van de werkgelegenheid, ook rekening zou moeten worden gehouden met de verwachte aanbodontwikkeling.

4 A. Nieuwland, J. Lelyveld, J. Hermsen, C. van der Elst, B. van Amstel, Het pilot-project I-SEE. Conclusies en aanbevelingen, Rijswijk, december 1987. 
Voor de beroepsklassen is dit evenwel weinig zinvol, omdat de instroom van afstuderenden zich primair kenmerkt door de gevolgde opleiding en niet door het uit te oefenen beroep.

Eveneens op verzoek van de ISBV-werkgroep automatisering, is bij de typering van de uitwijkmogelijkheden naar de verschillende bedrijfs- c.q. beroepsklassen uitgegaan van de in het vorige rapport aanvankelijk genoemde driedeling ${ }^{5}$, in plaats van de in dat rapport uiteindelijk gehanteerde tweedeling. Deze driedeling impliceert de volgende typering: weinig uitwijkmogelijkheden (kleine beroepenspreiding), enige uitwijkmogelijkheden (gemiddelde beroepenspreiding) of veel uitwijkmogelijkheden (grote beroepenspreiding).

\subsection{Correctie prognose theologie}

Tenslotte zijn enkele correcties aangebracht in de arbeidsmarktvoorspellingen voor de studierichting theologie. De belangrijkste verandering betreft de verwachte instroom van afstuderenden. Deze moest worden opgehoogd van $11 \%$ naar $23 \%$ van de werkgelegenheid in 1985 , omdat in de WORSA-prognoses waarvan door ons gebruik is gemaakt, vreemd genoeg geen rekening is gehouden met de afstuderenden bij de verschillende theologische universiteiten. Daarentegen is de voorspelde vervangingsvraag in benedenwaartse richting bijgesteld van $27 \%$ naar $21 \%$ van de werkgelegenheid in het begin van de voorspelperiode. Deze correctie is aangebracht om rekening te houden met het relatief omvangrijke aantal theologen dat werkzaam blijft na het bereiken van de 65-jarige leeftijd. Verondersteld is dat dit aantal in 1992 gelijk is aan het aantal werkende theologen ouder dan 65 jaar in 1985.

5 De Grip c.s., op cit., p. 15. 


\section{PERIODIEKE ACTUALISERING DATA}

Vanzelfsprekend zal de informatie van de arbeidsmarktmodule van I-SEE periodiek moeten worden geactualiseerd. Hoewel de arbeidsmarktprognoses naar alle waarschijnlijkheid met de komst van de Enquête Beroepsbevolking (E.B.B.) van het CBS in principe jaarlijks zouden kunnen worden geactualiseerd, verdient het vanuit kosten-baten overwegingen de voorkeur een dergelijke updating slechts eens in de twee jaar te laten plaatsvinden. Immers, het opstellen van nieuwe prognoses vereist iedere keer dat de gehele prognosecyclus van bedrijfstakkenvoorspelling naar beroepen- en opleidingenvoorspelling moet worden doorlopen, terwijl dergelijke middellange-termijn voorspellingen in de meeste gevallen van het ene jaar op het andere niet al te sterk zullen afwijken. Bovendien is het zinvol telkens voldoende tijd te nemen voor evaluatie en vernieuwing van de gevolgde aanpak.

Ook voor het merendeel van de historische data en de daaruit samengestelde indicatoren lijkt een twee-jaarlijkse updating een goede middenweg. Daarbij zou een uitzondering gemaakt kunnen worden voor de werkloosheidsgegevens. Deze vrij gemakkelijk te bewerken gegevens zouden dan kunnen fungeren als een meer permanente dijkbewaking met betrekking tot de situatie op de arbeidsmarkt. Voor dergelijke 'monotoring'-indicatoren is een halfjaarlijkse actualisering nodig.

Het ROA is ook verzocht een formulier te ontwerpen op basis warvan de periodiek geactualiseerde arbeidsmarktinformatie zou kunnen worden verwerkt in het IBO/I-SEE systeem. Een dergelijk formulier zou globaal dezelfde opzet kunnen hebben als de bijlagen I en II van dit rapport. Een meer voor de hand liggende methode om de informatie te actualiseren is echter het op diskette, of indien gewenst op magneetband, aanleveren van een ruwe data-file in standaardcodering ASCII. Met behulp van een bijbehorend inleesprogramma, zou op deze manier de updating van de informatie geheel kunnen worden geautomatiseerd. Voor het ontwerpen van een inleesprogramma, is het natuurlijk wel van belang op welke wijze het D-base systeem waarin I-SEE momenteel is geprogrammeerd, gekoppeld kan worden aan het op het Mistral-systeem gebaseerde IBO-bestand.

Het spreekt voor zich dat de uiteindelijke omvang en structuur van de tweejaarlijks op te leveren ruwe data-file, afhankelijk is van de mate waarin in 
de toekomst additionele gegevens vanuit deelstudies e.d. in het informatiesysteem kunnen worden verwerkt. Daar het hier gaat om een eerste opzet van een dergelijke data-file, hebben wij ons vooralsnog beperkt tot de actualisering van de CBS-werkgelegenheidsgegevens, de SZW-werkloosheidgegevens en de door het ROA samengestelde indicatoren en prognoses. Bijlage IV geeft een voorlopige indeling van dit databestand. Hierbij moet worden opgemerkt dat wanneer op een bepaald moment overwogen wordt additionele arbeidsmarktgegevens in het systeem op te nemen vanzelfsprekend niet alleen de opzet van de ruwe data-file, maar ook die van het inleesprogramma moet worden aangepast.

Tenslotte willen wij hier benadrukken dat aan de onderlinge afstemming van de arbeidsmarkt- en de beroepenmodule in de toekomst veel aandacht zal moeten worden besteed, met name wat betreft de gehanteerde beroepen- en bedrijfssectorenindeling en de daaraan gekoppelde benamingen. De arbeidsmarktmodule zal zich op dit punt moeten baseren op respectievelijk de CBSBeroepenclassificatie en de Standaard Bedrijfs Indeling (SBI). In de eerste plaats omdat alleen op deze wijze een consistente koppeling aan de macro- en meso-economische prognoses van het Centraal Planbureau (CPB) mogelijk is; in de tweede plaats omdat belangrijke basisgegevens van het CBS, zoals de Arbeidskrachtentellingen en de Enquête Beroepsbevolking, deze indelingen hanteren.

De door ons gehanteerde begrippen 'beroepsklasse, beroepsgroep en bedrijfsklasse' behoren dan ook tot de standaard CBS-terminologie en verwijzen derhalve expliciet naar de CBS-classificaties. Gezien de huidige tekortkomingen van vooral de beroepsklasse-indeling vanuit de optiek van de studie- en beroepskeuzebeslissingen, is er veel voor te zeggen om in het ISEE systeem andere beroepscategorieën af te bakenen ${ }^{6}, c . q$. andere beroepsbenamingen te gebruiken. Dit vereist echter nader onderzoek naar een vertaal-slag van de CBS-classificaties naar de I-SEE indelingen.

Het is wat dit betreft van groot belang dat er in I-SEE een indeling in beroepsdomeinen wordt gehanteerd, die vertaalbaar is naar de CBS-Beroepenclassificatie. De momenteel voorgestelde beroepenindeling op basis van een

6 Zie A. de Grip, L.F.M. Groot en J.A.M. Heijke, Clustering occupational classes by educational structure, ROA-W-1987/2E, Maastricht. 
kruising van 13 'sectoren in de arbeidswereld' en 9 'werksoorten' zal op dit punt kritisch moeten worden bekeken. Zo zijn de hierin onderscheiden sectoren niet volledig te koppelen aan de 24 bedrijfstakken waarvoor het CPB een middellange-termijn prognose opstelt.

Bovendien is de voorgestelde sectorindeling met het oog op de studie- en beroepskeuzevoorlichting weinig beter dan de CPB-indeling. In de eerstgenoemde indeling zijn vooral de commerciële en niet-comerciële dienstensector verbijzonderd, terwijl voor de industriële sectoren een te hoog aggregatieniveau is gehanteerd. In de CPB-indeling is het omgekeerde het geval. Wat dit betreft zouden beide indelingen elkaar goed kunnen aanvullen. De vertaalslag tussen beide indelingen zou dan moeten worden gemaakt met behulp van de meer gedesaggregeerde CBS-indeling in bedrijfsklassen.

Op soortgelijke wijze zal ook de indeling in 9 werksoorten kritisch moeten worden bezien. Hier ontbreken ons inziens bijvoorbeeld de werksoorten 'medisch' en 'onderwijs' als aparte categorieën. Bovendien zou de aanduiding 'uitvoerend werk' beter kunnen worden vervangen door de meer homogene categorie 'uitvoerend praktisch (produktie) werk'. Tenslotte zal natuurlijk ook kritisch gekeken moeten worden naar het totaalbeeld van de beroepsdomeinen, de 'cellen' van de matrix, die uit de voorgestelde beroepsdomeinenmatrix resulteren, om de vertaalbaarheid van de te maken indeling naar de CBS-beroepenclassificatie te waarborgen. Voor de duidelijkheid merken wij hier op dat het hierbij alleen gaat om de compatibiliteit van de gehanteerde indelingen. Bij de naamgeving van de onderscheiden sectoren, werksoorten en beroepsdomeinen is men daarentegen geheel vrij om afwijkende termen te gebruiken. 
B I JLAGEN 
BIJLAGE I: ARBEIDSMARKTDATA STUDIERICHTINGEN

Bron: ROA 
OVERZICHT VAN STUDIERICHTINGEN

\begin{tabular}{|c|c|c|}
\hline & SOI-code* & Bladzijde \\
\hline Letteren & 611 & 3 \\
\hline Theologie & 616 & 6 \\
\hline Agrarische Wetenschappen en Huishoudkunde & $\begin{array}{l}621,622, \\
623,629 \\
681\end{array}$ & 8 \\
\hline Wis- en Natuurkunde & 631 & 12 \\
\hline Technische Wetenschappen & $\begin{array}{l}636,638 \\
639\end{array}$ & 17 \\
\hline Medische Opleidingen & 651 & 21 \\
\hline Farmacologie & 652 & 24 \\
\hline $\begin{array}{l}\text { Economische Wetenschappen en Bedrijfskunde } \\
\text { (drs.) }\end{array}$ & 661 & 27 \\
\hline $\begin{array}{l}\text { Econometrie, Actuariaat en Bedrijfskunde } \\
\text { (ir.) }\end{array}$ & 662 & 30 \\
\hline Rechten & 666 & 32 \\
\hline Sociaal-Culturele Wetenschappen & 671 & 35 \\
\hline Kunstonderwijs & 686 & 38 \\
\hline MO-B Akten & 606 & 40 \\
\hline
\end{tabular}

*Standaard Onderwijs Indeling 1978, Centraal Bureau voor de Statistiek. 
VERKLARING VAN DE GEBRUIKTE TEKENS

* Gemiddelde op basis van de jaren 1979, 1981, 1983 en 1985.

** Op basis van een vergelijking tussen de jaren 1983 en 1985 ten opzichte van de jaren 1979 en 1981.

$++=$ sterk stijgend

$+=$ stijgend

$0=$ constant

- = dalend

-- = sterk dalend

Voor de hierbij gehanteerde classificatiecriteria zie bijlage III.

*** Deze ratio geeft het werkloosheidspercentage ten opzichte van het gemiddelde werkloosheidspercentage van academici $(7 \%)$ weer.

$* * * *$ Het betreft hier het quotiënt van de instroom van afstuderenden en de totale vraag naar nieuwkomers in de periode 1985-1992.

\# Te gering percentage of aantal (zie paragraaf 2.2). 


\section{LETTEREN}

Code (s): 611

HISTORISCHE DATA

$\underline{t r e n d * *}$

I. Gemiddeld aantal werkenden 1979 - 1985*:

- absoluut aantal:

- in \% van het totaal aantal werkenden:

14.500

- in \% van het totaal aantal werkenden met een universitaire opleiding :

$\begin{array}{ll}0.29+ \\ 7.0 & 0\end{array}$

II. Belangrijkste beroepsklassen waarin men werkzaam is: (gemiddeld percentage $1979-1985 *$ )

1. (13) Leerkrachten

2. (19) Diverse wetenschappelijke e.a. vakspecialisten

w.v. (195) taalkundigen, vertalers en tolken

3. (15) Auteurs, journalisten e.d.

4. (39) Diverse administratieve functies

5. (21) Beleidvoerende en hogere leidinggevende functies (exclusief openbaar bestuur)

III. Gemiddeld aandeel in de werkgelegenheid van de beroepsklasse 1979 - 1985*:

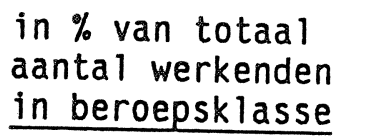

1. (13) Leerkrachten

2. (19) Diverse wetenschappelijke e.a. vakspecialisten

$\begin{array}{lc}4 & + \\ 3 & + \\ \text { in \% van aantal } & \text { trend** } \\ \text { univ. geschoolden } & \\ \text { in beroepsklasse } & \end{array}$

1. (13) Leerkrachten

2. (19) Diverse wetenschappelijke

21 0 e.a. vakspecialisten 
IV. Werkloosheid:

\begin{tabular}{|c|c|c|c|c|c|}
\hline & $\begin{array}{l}\% \text { werk- } \\
\text { loosheid } \\
1985 \\
\end{array}$ & $\begin{array}{l}\text { relatieve } \\
\text { werkloos- } \\
\text { heid } \star \star \star \\
\end{array}$ & $\begin{array}{l}\text { trend } \\
\star \star \star \\
\end{array}$ & $\begin{array}{l}\text { aandeel } \\
\text { werkl. } \\
\text { nieuwk. }\end{array}$ & $\begin{array}{l}\text { aandeel } \\
\text { langd. } \\
\text { werkl. }\end{array}$ \\
\hline $\begin{array}{l}\text { - Totaal letteren } \\
\text { - Nederlands } \\
\text { - Duits } \\
\text { - Frans } \\
\text { - Engels } \\
\text { - Wijsbegeerte } \\
\text { - Geschiedenis } \\
\text { - Slavische talen } \\
\text { - Spaans } \\
\text { - Scandinavische } \\
\text { - talen } \\
\text { - Latijn } \\
\text { - Grieks } \\
\text { - Archeologie } \\
\text { - Algemene taal-en } \\
\text { literatuurweten- } \\
\text { schappen }\end{array}$ & $\begin{array}{l}15 \\
18 \\
12 \\
10 \\
10 \\
25\end{array}$ & $\begin{array}{l}2.2 \\
2.6 \\
1.7 \\
1.4 \\
1.4 \\
3.6\end{array}$ & $\begin{array}{l}++ \\
++ \\
++ \\
++ \\
++ \\
++ \\
++ \\
++ \\
++ \\
\\
++ \\
++ \\
++ \\
++\end{array}$ & $\begin{array}{l}51 \\
45 \\
48 \\
46 \\
49 \\
51 \\
58 \\
53 \\
50 \\
68 \\
42 \\
43 \\
49\end{array}$ & $\begin{array}{l}53 \\
49 \\
53 \\
50 \\
46 \\
63 \\
57 \\
60 \\
57 \\
57 \\
48 \\
46 \\
54 \\
\\
52\end{array}$ \\
\hline $\begin{array}{l}\text { - Belangrijkste beroe } \\
\text { - vakleraren } \\
\text { - geschiedkundigen } \\
\text { - auteurs }\end{array}$ & pen van $i$ & ijving: & & & \\
\hline
\end{tabular}

\section{INDICATOREN}

HG-ratio kwalificatie trend**

Beroepenspreiding:

$\begin{array}{llll}\left.\text { (gemiddelde } 1979-1985^{\star}\right) & 0.53 & \text { gemiddeld } & 0\end{array}$

\section{PROGNOSES}

Arbeidsmarktontwikkeling 1985 - 1992:

(in \% werkgelegenheid in 1985)

$\begin{array}{lcl} & \% & \text { kwalificatie } \\ \begin{array}{l}\text { Werkgelegenheidsontwikkeling } \\ \text { Vervangingsvraag }\end{array} & 13 & \text { laag } \\ \text { Totale vraag naar nieuwkomers } & \frac{7}{20} & \begin{array}{l}\text { laag } \\ \text { laag }\end{array} \\ \begin{array}{l}\text { Instroom afgestudeerden } \\ \begin{array}{l}\text { Indicator arbeidsmarktsituatie } \\ \text { voor afgestudeerden in 1992 } \star \star \star \star *\end{array}\end{array} & 126 & \text { erg hoog } \\ & 7.1 & \begin{array}{l}\text { slecht arbeids- } \\ \text { marktperspectief }\end{array}\end{array}$


TYPERING

Momenteel is de WERKLOOSHEID onder de afgestudeerden in deze studierichting HOOG, vergeleken met het gemiddelde van academici. ook voor de nabije toekomst zijn de ARBEIDSMARKTPERSPECTIEVEN SLECHT als gevolg van een LAGE GROEI van de WERKGELEGENHEID en een LAGE VERVANGINGSVRAAG vanwege pensionering, e.d., terwijl de INSTROOM VAN AFSTUDERENDEN op de arbeidsmarkt ERG HOOG zal zijn. Wel blijken er op de arbeidsmarkt ENIGE UITWIJKMOGELIJKHEDEN naar andere beroepen te bestaan.

\section{AANVULLENDE GEGEVENS}

Werkterreinen van afgestudeerde Neerlandici van de RUU in de jaren 1978-1985:

$\begin{array}{lr} & \\ \text { Onderwijs } & \\ \text { Universiteiten } & 50 \\ \text { Planning \& beleid } & 12 \\ \text { Voorlichting, PR \& reclame : } & \# \\ \text { Niet-reguliere opleidingen: } & \# \\ \text { Bibliotheken/archief } & \#\end{array}$

Bron: Doeksen en Jansen, 1986. 
THEOLOGIE

Code $(s): 616$

HISTORISCHE DATA

trend**

I. Gemiddeld aantal werkenden 1979 - 1985*:

- absoluut aantal:

- in \% van het totaal aantal werkenden:

- in \% van het totaal aantal werkenden met een universitaire opleiding :

5.900

$\begin{array}{ll}0.12+ \\ 2.8 & 0\end{array}$

II. Belangrijkste beroepsklassen warin men werkzaam is: (gemiddeld percentage $1979-1985^{\star}$ )

1. (14) Bedienaars van de eredienst en verwante functies

2. (13) Leerkrachten

3. (19) Diverse wetenschappelijke e.a. vakspecialisten

4. (21) Beleidvoerende en hogere leiding-

gevende functies (excl. openbaar bestuur)

\% $\quad \underline{\text { trend**}}$

III. Gemiddeld aandeel in de werkgelegenheid van de beroepsklasse 1979 - 1985*:

\section{in $\%$ van totaal aantal werkenden \\ in beroepsklasse}

$\underline{\text { trend** }}$

1. (14) Bedienaars van de eredienst en verwante functies

2. (13) Leerkrachten

45

0

in $\%$ van aantal univ. geschoolden in beroepsklasse

1. (14) Bedienaars van de eredienst en verwante functies w.v. (141) bedienaars van de eredienst 65

2. (13) Leerkrachten 
IV. Werkloosheid:

\begin{tabular}{|c|c|c|c|c|c|}
\hline & $\begin{array}{l}\% \text { werkloos- } \\
\text { heid } 1985\end{array}$ & $\begin{array}{l}\text { relatieve } \\
\text { werkloos- } \\
\text { heid } \star \star \star \\
\end{array}$ & $\begin{array}{c}\text { trend } \\
\star \star\end{array}$ & $\begin{array}{l}\text { aandee } 1 \\
\text { werk 1. } \\
\text { nieuwk. }\end{array}$ & $\begin{array}{l}\text { aandee } 1 \\
\text { langd. } \\
\text { werk1. }\end{array}$ \\
\hline totaal theologie & 3 & 0.4 & ++ & 48 & 58 \\
\hline
\end{tabular}

- Belangrijkste beroepen van inschrijving: $(\%)$

- vakleraren 35

- geestelijken 26

- sociaal wetenschappelijke onderzoekers 5

- maatschappelijk werkenden 5

- Werkloosheid relatief hoog in provincies: Overijssel en Noord-Brabant

\title{
INDICATOREN
}

\author{
HG-ratio kwalificatie trend** \\ Beroepenspreiding: \\ (gemiddelde $1979^{-1985^{*}}$ ) 0.49 gemiddeld + \\ PROGNOSES \\ Arbeidsmarktontwikkeling 1985 - 1992: \\ (in \% werkgelegenheid in 1985)

$\begin{array}{lcl}\text { Werkgelegenheidsontwikkeling } & \frac{\%}{\text { kwalificatie }} \\ \begin{array}{l}\text { Vervangingsvraag } \\ \text { Totale vraag naar nieuwkomers }\end{array} & 5 & \begin{array}{l}\text { erg laag } \\ \text { erg hoog } \\ \text { gemiddeld }\end{array} \\ \begin{array}{l}\text { Instroom afgestudeerden } \\ \text { Indicator arbeidsmarktsituatie }\end{array} & 23 & \text { erg laag } \\ \text { voor afgestudeerden in 1992 **** } & 1.0 & \begin{array}{l}\text { goed arbeids- } \\ \text { marktperspectief }\end{array}\end{array}$ \\ TYPERING \\ Momenteel is de WERKLOOSHEID onder de afgestudeerden in deze stu- \\ dierichtingen LAAG, vergeleken met het gemiddelde van academici. \\ Ook voor de nabije toekomst zijn de ARBEIDSMARKTPERSPECTIEVEN GOED. \\ Weliswaar is de voorspelde WERKGELEGENHEIDSGROEI ERG LAAG maar daar- \\ tegenover staat dat de VERVANGINGSVRAAG vanwege pensionering, e.d. \\ ERG HOOG is, terwijl de INSTROOM VAN AFSTUDERENDEN op de arbeidsmarkt \\ ERG LAAG zal zijn. \\ Bovendien blijken er op de arbeidsmarkt ENIGE UITWIJKMOGELIJKHEDEN \\ naar andere beroepen te bestaan.
}


AGRARISCHE WETENSCHAPPEN EN HUISHOUDKUNDE ${ }^{1}$ )

Code $(s): 621,622,623,629,681$

HISTORISCHE DATA

$\underline{\text { trend } \star *}$

I. Gemiddeld aantal werkenden 1979 - 1985*:

- absoluut aantal:

- in \% van het totaal aantal werkenden:

- in \% van het totaal aantal werkenden met een universitaire opleiding :

4.800

$0.09++$

$2.2+$

II. Belangrijkste beroepsklassen waarin men werkzaam is: (gemiddeld percentage $1979-1985 *$ )

\section{\% $\quad$ trend**}

1. (05) Biologen, biochemici, landbouwkundigen en verwante vakspecialisten

w.v. (53) hogere landbouwkundigen, e.d.

2. (13) Leerkrachten

3. (02) Architecten, ingenieurs en verwante technici

4. (21) Beleidvoerende en hogere leidinggevende functies (excl. openbaar bestuur)

5. (19) Diverse wetenschappelijke e.a. vakspecialisten

6. (31) Uitvoerende hoofdambtenaren

7. (33) Bankemployés, lokettisten e.d.

8. (60) Bedrijfsleiders land- en tuinbouw e.d.

9. (09) Economen

10. (39) Diverse administratieve functies

11. (45) Toezichthoudend- en leidinggevend commercieel personeel

12. (20): Beleidvoerende en hogere leidinggevende functies bij openbaar bestuur

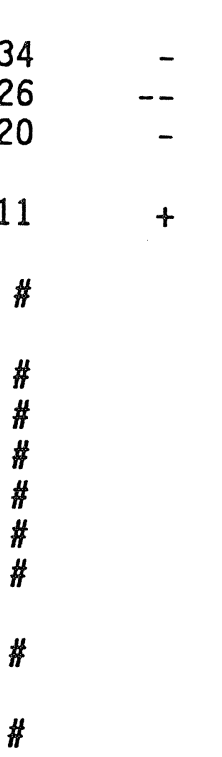

${ }^{1}$ De hier gepresenteerde arbeidsmarktinformatie omvat, in tegenstelling tot wat de naam 'Agrarische Wetenschappen' misschien suggereert, niet alle studierichtingen die aan de Landbouw Universiteit Wageningen gevolgd kunnen worden. Zo ressorteert de studierichting Levensmiddelentechnologie onder de technische wetenschappen, de richting Rurale Sociologie onder de sociaal-culturele wetenschappen, de richting Agrarische Economie onder de economische wetenschappen en de studierichting Biologie onder wiskunde en natuurwetenschappen. De desbetreffende indeling is conform de Standaard Onderwijs Indeling (S.O.I.) van het
CBS. 
III. Gemiddeld aandeel in de werkgelegenheid van

de beroepsklasse 1979 - 1985*:

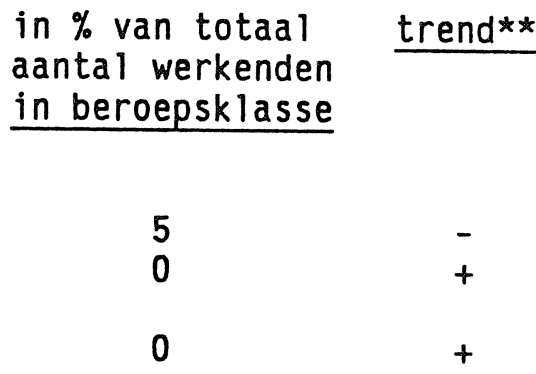

in $\%$ van aantal trend** univ. geschoolden in beroepsklasse

1. (05) Biologen, biochemici, landbouwkundigen en verwante vakspecialisten

2. (13) Leerkrachten

3. (02) Architecten, ingenieurs en verwante technici

IV. Werkloosheid:

- Totaal agrarische wetenschappen

- Tropische landbouwwetenschappen

- Cultuurtechniek

- Plantenveredeling

- Plantenziektekunde

- Milieuhygiëne

- Bodemkunde/bemestings leer

- Bosbouw

- Plantenteelt

- Zoötechniek

- Tuin- en landschapsarchitectuur

- Landbouwtechniek

- Huishoudkunde

\begin{tabular}{lll}
$\%$ werkloos- ratio trend $\begin{array}{l}\text { aandeel } \\
\text { werkl. }\end{array}$ & $\begin{array}{l}\text { aandeel } \\
\text { langd. } \\
\text { heid } 1985\end{array}$ \\
\hline
\end{tabular}

- Belangrijkste beroepen van inschrijuing:

- consulenten, e.d.

11

1.6

55

42

$+$

50

- cultuurtechnici

- plant, dier- en bodemkundigen

- bosbouwkundigen

- landschaps - en tuinarchitecten

$+\quad 64 \quad 65$

$+57 \quad 52$

$+\quad 32$

52

Werkloosheid relatief hoog in provincie: Gelderland. 


\section{INDICATOREN}

\section{$\underline{\text { HG-ratio }} \quad$ kwalificatie trend**}

Beroepenspreiding:

(gemiddelde 1979 - $1985^{\star}$ )

0.82 groot

$+$

PROGNOSES

Arbeidsmarktontwikkeling 1985 - 1992:

(in \% werkgelegenheid in 1985)

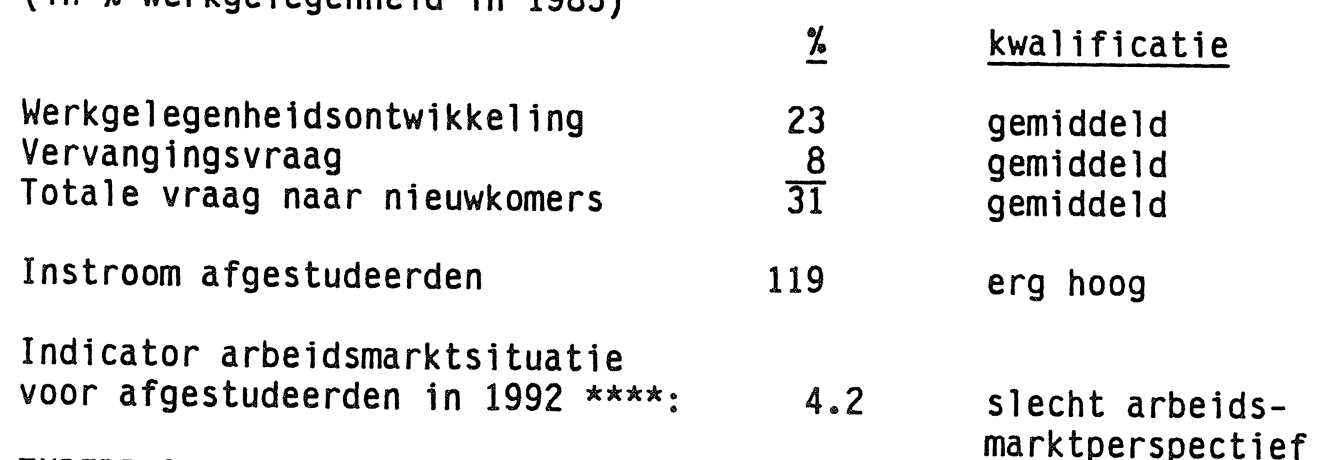

\section{TYPERING}

marktperspectief

Momenteel is de WERKLOOSHEID onder de afgestudeerden in deze studierichting HOOG, vergeleken met het gemiddelde van academici.

ook voor de nabije toekomst zijn de ARBEIDSMARKTPERSPECTIEVEN SLECHT. Wel iswaar is de voorspelde WERKGELEGENHEIDSGROEI REDELIJK evenals de VERVANGINGSVRAAG vanwege pensionering, e.d., maar daartegenover staat een ERG HOGE INSTROOM VAN AFSTUDERENDEN op de arbeidsmarkt.

Wel blijken er op de arbeidsmarkt VEEL UITWIJKMOGELIJKHEDEN naar andere beroepen te bestaan. 


\section{AANVULLENDE GEGEVENS}

Functie-omschrijving werkzame afgestudeerden van LU Wageningen
$(1983)^{2):}$

Onderzoeker

Leidinggevend onderzoeker

17

Hoogleraar

Leraar

Voorlichter

Ontwikkelingsdeskundige

11

Beleidsmedewerker

Hoofd van een afdeling

6

Commercieel medewerker

Directeur

Voorzitter, secretaris

Beheerder

Informatiespecialist

Ontwerper

Ondernemer

Bron: NILI-Loopbaanenquête, 1983

Marktsectoren waar pas-afgestudeerden van de LU-Wageningen in 1983 terecht kwamen:

LH, universiteiten en hogescholen

Algemeen voortgezet en beroepsonderwijs

Onderzoeksinstituten

Ministerie van landbouw en visserij

Overige rijksoverheid

Regionale en lokale overheid

Voedings- en voedermiddelen-industrie en -handel

12

10

Overige industrie en handel

Organisaties en verenigingen

Dienstverlening en vrij beroep

Internationale organisaties, buitenlandse overheid en

Directoraal Generaal internationale samenwerking

Bron: NILI-10opbaanenquête 1983

2 Zoals reeds opgemerkt gaat het hier om meer studierichtingen dan door ons, in navolging van het CBS, tot de agrarische wetenschappen worden gerekend. 


\section{WIS- EN NATUURKUNDE}

Code (s): 631

\section{HISTORISCHE DATA}

$\underline{\text { trend** }}$

I. Gemiddeld aantal werkenden 1979 - 1985*:

- absoluut aantal:

- in \% van het totaal aantal werkenden:

- in \% van het totaal aantal werkenden met een universitaire opleiding :

21.100

$$
0.420
$$

$10.3+$

II. Belangrijkste beroepsklassen waarin men werkzaam is:

(gemiddeld percentage $1979-1985 \star$ )

1. (13) Leerkrachten

2. (01) Schei-, natuurkundigen en verwante technici

w.v. (011) scheikundigen (012) natuurkundigen

3. (05) Biologen, biochemici, landbouwkundigen en verwante vakspecialisten

$w . v .(051)$ biologen, zoölogen, botanici, 14 (052) hogere biochemici, farmacologen, e.d. 5

4. (08) Statistici, wiskundigen, systeemanaliten en verwante vakspecialisten

5. (02) Architecten, ingenieurs en verwante technici

6. (19) Diverse wetenschappelijke e.a. vakspecialisten

7. (21) Beleidvoerende en hogere leidingge33 gevende functies (ecxl. openbaar b

8. (39) Diverse administratieve functies 
III. Gemiddeld aandee 1 in de werkgelegenheid van de beroepsklasse 1979 - 1985*:

\section{in $\%$ van totaal aantal werkenden in beroepsklasse} $\underline{\text { trend** }}$

1. (13) Leerkrachten

2. (01) Schei-, natuurkundigen en verwante technici

3

13

12

0 bouwkundigen en verwante vakspecialisten

4. (08) Statistici, wiskundigen, systeemanalisten en verwante vakspecialisten

5. (02) Architecten, ingenieurs en verwante technici

6. (19) Diverse wetenschappelijke e.a. vakspecialisten

7. (21) Beleidvoerende en hogere leidinggevende functies (excl. openbaar bestuur)

$\begin{array}{rr}4 & - \\ 1 & 0 \\ 1 & ++ \\ 1 & +\end{array}$

in \% van aantal trend** univ. geschoolden in beroepsklasse

1. (13) Leerkrachten

2. (01) Schei- natuurkundigen en verwante technici

3. (05) Biologen, biochemici, landbouwkundigen en verwante vakspecialisten

5. (02) Architecten, ingenieurs en systeemanalisten en verwante vakspecialisten verwante technici

6. (19) Diverse wetenschappelijke e.a. vakspecialisten

7. (21) Beleidvoerende en hogere leidinggevende functies (excl. openbaar bestuur) 
IV. Werkloosheid:
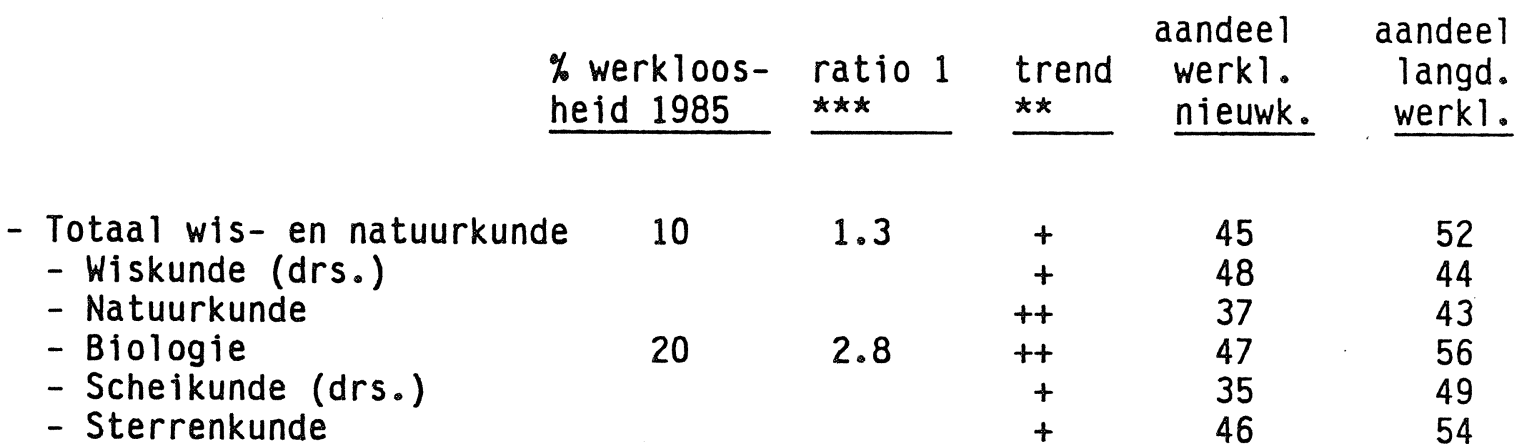

$\begin{array}{ccccc}10 & 1.3 & + & 45 & 52 \\ & & + & 48 & 44 \\ & & ++ & 37 & 43 \\ 20 & 2.8 & ++ & 47 & 56 \\ & & + & 35 & 49 \\ & & + & 46 & 54\end{array}$

- Belangrijkste beroepen van inschrijving:

- plant-, dier- en bodemdeskundigen

$(\%)$

- vakleraren

- wis- en natuurkundigen

- scheikundigen

- aardkundig onderzoekers

INDICATOREN

$\underline{H G \text {-ratio kwalificatie trend** }}$

Beroepenspreiding:

(gemiddelde $1979-1985^{*}$ ) 0.81 groot +

\section{PROGNOSES}

Arbeidsmarktontwikkeling 1985 - 1992:

(in \% werkgelegenheid in 1985)

\section{$\% \quad$ kwalificatie}

Werkgelegenheidsontwikkeling

24 gemiddeld

Vervangingsvraag

Totale vraag naar nieuwkomers

$7 \quad$ laag

$\overline{31} \quad$ gemiddeld

Instroom afgestudeerden

79 erg hoog

Indicator arbeidsmarktsituatie

voor afgestudeerden in $1992 * \star \star \star *$ :

2.9 matig arbeidsmarktperspectief 


\section{TYPERING}

Momenteel is de WERKLOOSHEID onder de afgestudeerden in deze studierichtingen $H O O G$, vergeleken met het gemiddelde van academici. Ook voor de nabije toekomst zijn de ARBEIDSMARKTPERSPECTIEVEN maar MATIG.

Weliswaar is de voorspelde WERKGELEGENHEIDSGROEI REDELIJK, maar de VERVANGINGSVRAAG vanwege pensionering, e.d. is LAAG, terwijl de INSTROOM VAN AFSTUDERENDEN op de arbeidsmarkt ERG HOOG zal zijn. Wel blijken er op de arbeidsmarkt ENIGE UITWIJKMOGELIJKHEDEN naar andere beroepen te bestàán.

\section{AANVULLENDE GEGEVENS}

Belangrijkste werkterreinen van afgestudeerde biologen 3 )

(1983)

$(\%)$

- onderzoeksinstituten en universiteiten

- onderwijsinstellingen

53

- overheidsinstanties

- non-profit organsiaties

- bedrijfsleven

Bron: Tichelaar, 1987

Belangrijkste werkterreinen van in Nederland afgestudeerde natuurkundigen (1983)

- buitenland

- universiteiten/hogescholen

- overheid

- industrie

Bron: Lingeman, 1984.

${ }^{3}$ De cijfers hebben alleen betrekking op degenen die afstudeerden in de periode 1977-1983. 
Eerste baan van afgestudeerde biochemici en biofysici (in de periode 1978-1985)

\begin{tabular}{|c|c|}
\hline biochemici & biofysici \\
\hline \% & $\%$ \\
\hline 24 & \\
\hline $\begin{array}{r}7 \\
25\end{array}$ & $\begin{array}{l}28 \\
12 \\
12\end{array}$ \\
\hline
\end{tabular}

Bedrijfsleven: $\quad 7$

15

Overheid:

Ziekenhuizen:

Buitenland:

- WO-biofysica

12

- WO-anders

$\#$

\#

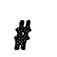

\#

$\#$

\#

Bron: KNAW - Commissie Biochemie en Biofysica, 1987. 
TECHNISCHE WETENSCHAPPEN

Code (s): 636, 638, 639

HISTORISCHE DATA

$\underline{\text { trend }} * \star$

I. Gemiddeld aantal werkenden 1979 - 1985*:

- absoluut aantal:

- in \% van het totaal aantal werkenden:

- in \% van het totaal aantal werkenden met een universitaire opleiding :

32.500

$0.64+$

$15.7 \quad 0$

II. Belangrijkste beroepsklassen waarin men werkzaam is: (gemiddeld percentage $1979-1985^{*}$ )

\% $\quad \underline{\text { trend*** }}$

1. (02) Architecten, ingenieurs en verwante technici

w.V. (021) architecten, stedebouwkundigen

(022) hogere bouwkundigen

(025) hogere werktulgbouwkundigen

(023) hogere electrotechnici, electronici

2. (21) Beleidvoerende en hogere leidinggevende

functies (excl. openbaar bestuur)

3. (13) Leerkrachten

4. (08) Statistici, wiskundigen, systeemanalisten en verwante vakspecialisten

5. (19) Diverse wetenschappelijke e.a. vakspecialisten

6. (01) Schei-, natuurkundigen en verwante technici

$\begin{array}{rr}53 & - \\ 9 & 0 \\ 9 & -- \\ 9 & -- \\ 7 & --\end{array}$

7. (70) Toezichthoudend- leidinggevend produktiepersonee 1

8. (31) Uitvoerende hoofdambtenaren 
III. Gemiddeld aandeel in de werkgelegenheid van de beroepsklasse 1979 - 1985*:

\section{in $\%$ van totaal trend $\star \star *$ aantal werkenden \\ in beroepsklasse}

1. (02) Architecten, ingenieurs en verwante technici

2. (21) Beleidvoerende en hogere leidinggevende functies (excl. openbaar bestuur)

3. (13) Leerkrachten Leerkrachten

4. (08) Statistici, wiskundigen, systeemanalisten en verwante vakspecialisten

$\begin{array}{ll}10 & + \\ 3 & 0 \\ 1 & \\ & \\ 5 & +\end{array}$

in $\%$ van aantal trend** univ. geschoolden

in beroepsklasse

1. (02) Architecten, ingenieurs en verwante technici

2. (21) Beleidvoerende en hogere leidinggevende functies (excl. openbaar bestuur)

3. (13) Leerkrachten

$28 \quad 0$

4. (08) Statistici, wiskundigen, sys-

8

$+$ teemanalisten en verwante vakspecialisten 
IV. Werkloosheid:

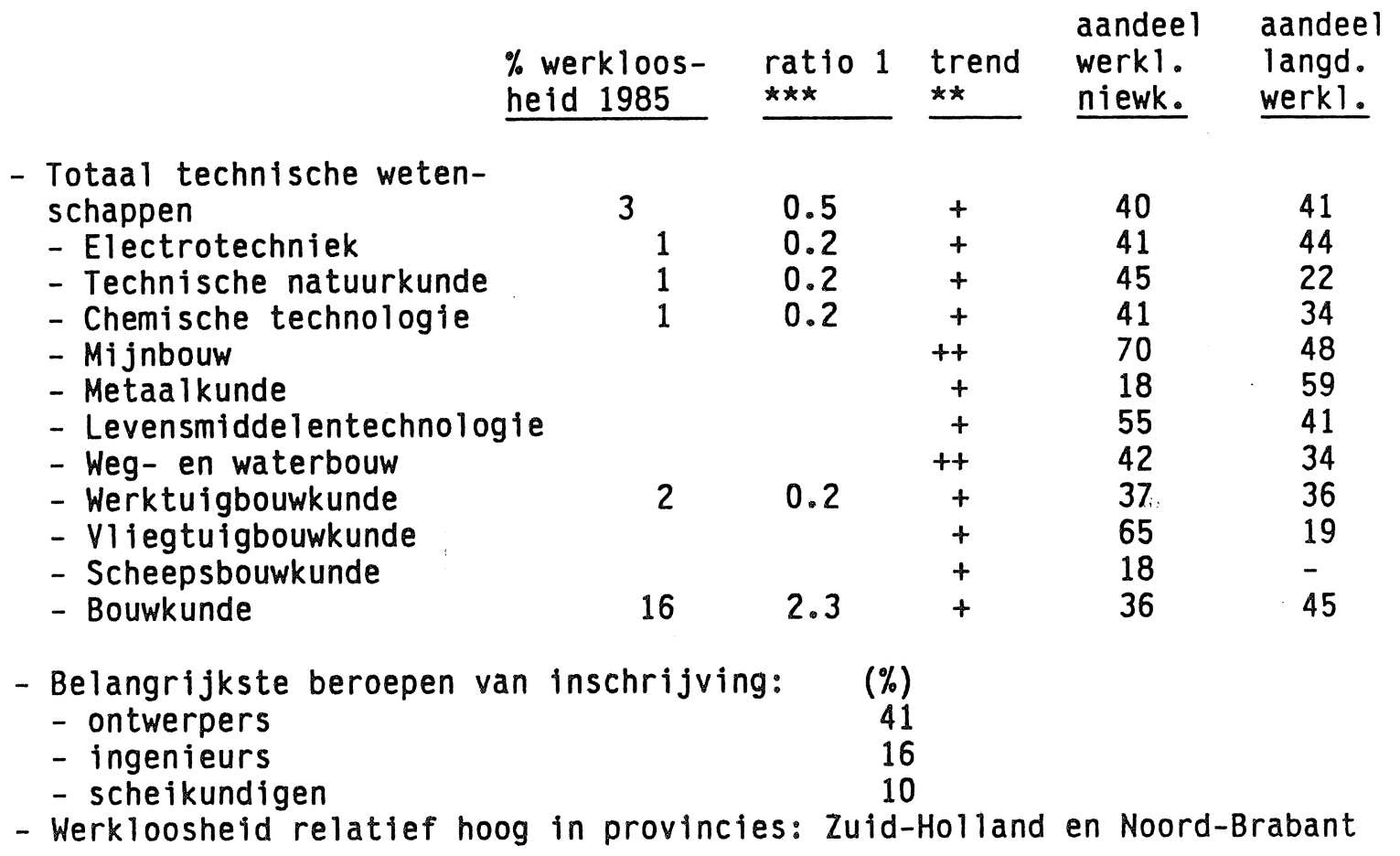

\section{INDICATOREN}

\section{HG-ratio kwalificatie trend**}

Beroepenspreiding:

(gemiddelde $1979-1985^{\star}$ ) 0.68 gemiddeld +

\section{PROGNOSES}

Arbeidsmarktontwikkeling 1985 - 1992:

(in \% werkgelegenheid in 1985)

Werkgelegenheidsontwikkeling

kwalificatie

Vervangingsvraag

46 erg hoog

Totale vraag naar nieuwkomers

10 hoog

Instroom afgestudeerden

$47 \quad$ hoog

Indicator arbeidsmarktsituatie

voor afgestudeerden in $1992 * * * *$ :

0.9 goed arbeids-

marktperspectief 
TYPERING

Momenteel is de WERKLOOSHEID onder de afgestudeerden in deze studierichting LAAG, vergeleken met het gemiddelde van academici.

Ook voor de nabije toekomst zijn de ARBEIDSMARKTPERSPECTIEVEN GOED. Wel iswaar zal de INSTROOM VAN AFSTUDERENDEN op de arbeidsmarkt HOOG zijn, maar daartegenover staat een ERG HOGE WERKGELEGENHEIDSGROEI en een HOGE

VERVANGINGVRAAG vanwege pensionering, e.d.

Bovendien blijken er op de arbeidsmarkt ENIGE UITWIJKMOGELIJKHEDEN

naar andere beroepen te bestaan. 
MEDISCHE OPLEIDINGEN

Code (s): 651

HISTORISCHE DATA

$\underline{\text { trend** }}$

I. Gemiddeld aantal werkenden 1979 - 1985*:

- absoluut aantal:

- in \% van het totaal aantal werkenden:

- in \% van het totaal aantal werkenden met een universitaire opleiding :

32.700

$\begin{array}{cc}0.65 & + \\ 15.8 & 0\end{array}$

II. Belangrijkste beroepsklassen waarin men werkzaam is: (gemiddeld percentage $1979-1985 *$ )

\% $\quad \underline{\text { trend** }}$

1. (06) Genees- en tandheelkundigen, dierenartsen, verplegenden en verwante vakspecialisten

w.V. (061) geneeskundigen

(063) tandheelkundigen

(065) diergeneeskundigen

2. (13) Leerkrachten

3. (05) Biologen, biochemici, landbouwkundigen en verwante vakspecialisten

4. (21) Beleidvoerende en hogere leidinggevende functies (excl. openbaar bestuur)

5. (19) Diverse wetenschappelijke e.a. vakspecialisten

III. Gemiddeld aandeel in de werkgelegenheid van de beroepsklasse 1979 - 1985*:

\section{in $\%$ van totaal trend** aantal werkenden in beroepsklasse}

1.(06) Genees- en tandheelkundigen, dierenartsen, verplegenden en verwante vakspecialisten

1. (06) Genees- en tandheelkundigen, dierenartsen, verplegenden en verwante vakspecialisten 
IV. Werkloosheid:

\begin{tabular}{|c|c|c|c|c|c|}
\hline & $\begin{array}{l}\% \text { werkloos- } \\
\text { heid } 1985 \\
\end{array}$ & $\begin{array}{l}\text { ratio } 1 \\
\star \star \star \star\end{array}$ & $\begin{array}{l}\text { trend } \\
\star \star \\
\end{array}$ & $\begin{array}{l}\text { aandeel } \\
\text { werkl. } \\
\text { nieuwk. }\end{array}$ & $\begin{array}{l}\text { aandeel } \\
\text { langd. } \\
\text { werkl. }\end{array}$ \\
\hline $\begin{array}{l}\text { - Totaal medische op- } \\
\text { leidingen } \\
\text { - Geneeskunde } \\
\text { - Tandheelkunde } \\
\text { - Diergeneeskunde }\end{array}$ & $\begin{array}{l}6 \\
7 \\
9 \\
4\end{array}$ & $\begin{array}{l}0.9 \\
1.0 \\
1.3 \\
0.5\end{array}$ & $\begin{array}{l}++ \\
++ \\
++ \\
+\end{array}$ & $\begin{array}{l}56 \\
53 \\
64 \\
64\end{array}$ & $\begin{array}{l}36 \\
37 \\
39 \\
17\end{array}$ \\
\hline $\begin{array}{l}\text { - Belangrijkste beroepen var } \\
\text { - artsen } \\
\text { - sociaal-geneeskundigen } \\
\text { - diergeneeskundigen } \\
\text { - specialisten }\end{array}$ & an inschrijui & & $\begin{array}{r}(\%) \\
41 \\
14 \\
9 \\
7\end{array}$ & & \\
\hline
\end{tabular}

\section{INDICATOREN}

\section{HG-ratio kwalificatie trend**}

Beroepenspreiding:

(gemiddelde $1979-1985^{*}$ ) 0.22 klein +

\section{PROGNOSES}

Arbeidsmarktontwikkeling 1985 - 1992:

(in \% werkgelegenheid in 1985)

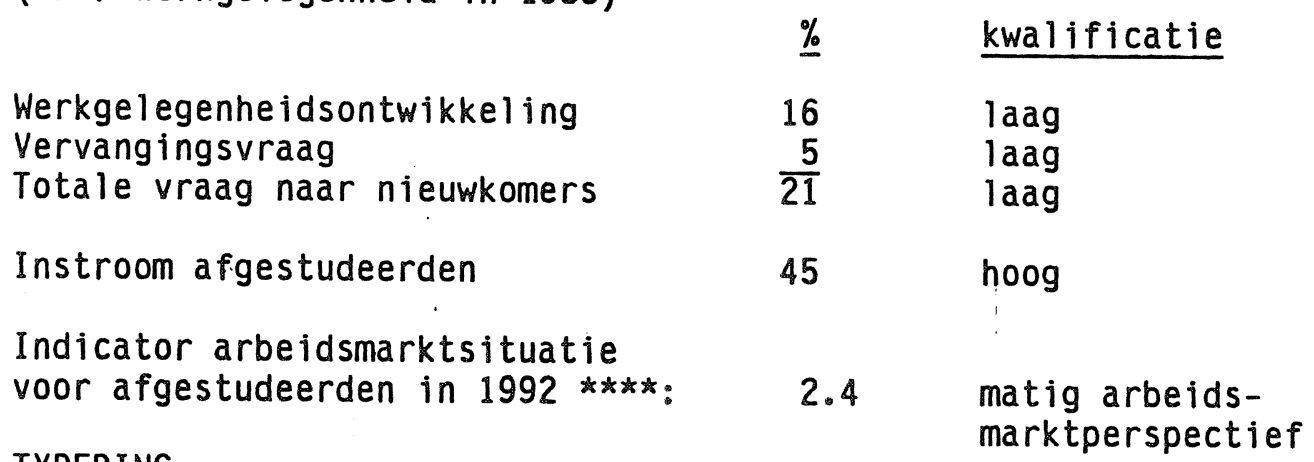

TYPERING

Momenteel is de WERKLOOSHEID onder de afgestudeerden in deze studierichtingen GELIJK AAN HET GEMIDDELDE van academici. Ook voor de nabije toekomst zijn de ARBEIDSMARKTPERSPECTIEVEN maar MATIG, als gevolg van een LAGE WERKGELEGENHEIDSGROEI en een LAGE VERVANGINGSVRAAG vanwege pensionering, e.d., terwijl de INSTROOM VAN AFSTUDERENDEN op de arbeidsmarkt HOOG zal zijn. Bovendien blijken er op de arbeidsmarkt maar WEINIG UITWIJKMOGELIJKHEDEN naar nadere beroepen te bestaan. 


\section{AANVULLENDE GEGEVENS}

\section{Huisartsen}

- Totaal aantal huisartsen (januari 1987): 6205.

- De gemiddelde wachttijd voor de huisartsenopleiding is vanaf 1973 jaarlijks met enkele maanden toegenomen tot ruim 32 maanden in 1986.

- Het totaal aantal praktijk-zoekende adspirant-huisartsen (d.w.z. werkloze huisartsen) neemt jaarlijks toe, tot 566 op 1 januari 1987.

Bron: Nive1, 1987.

\section{Tandheelkunde}

Werkterreinen van afgestudeerden in de tandheelkunde voor zover werkzaam als arts (1985):

$\begin{array}{lr} & \% \\ \text { - Algemene praktijken en schooltandverzorging } & 83 \\ \text { - Specialisten (praktijken) } & 6 \\ \text { - wetenschappelijk onderwijs } & 7 \\ \text { - overige diensten en instellingen } & \#\end{array}$

Bron: Eindrapport Commissie Opleiding Tandarts november 1985.

\section{Diergeneeskunde}

Werkterreinen van afgestudeerden in de diergeneeskunde (januari 1988):

- dierenarts

- wetenschappelijk onderwijs

- keuringsdiensten van waren, slachthuizen

- staatstoezicht op volksgezondheid, veterinaire diensten

- particuliere instellingen

- andere overheden

Bron: Koninklijke Nederlandse Maatschappij voor Diergeneeskunde, jaarboek 1987 . 


\section{FARMACOLOGIE}

Code (s): 652

HISTORISCHE DATA

I. Gemiddeld aantal werkenden 1979 - 1985*:

- absoluut aantal:

- in \% van het totaal aantal werkenden:

- in \% van het totaal aantal werkenden met een universitaire opleiding :

$\begin{array}{ll}0.04 & + \\ 1.0 & 0\end{array}$

II. Belangrijkste beroepsklassen waarin men werkzaam is: (gemiddeld percentage $1979-1985 *$ )

\% $\quad \underline{\text { trend** }}$

1. (06) Genees - en tandheelkundigen, dierenartsen, verplegenden en verwante vakspecialisten

w.v. (067) apothekers

(061) geneeskundigen

2. (05) Biologen, biochemici, landbouwkundigen en verwante vakspecialisten

3. (13) Leerkrachten

4. (21) Beleidvoerende en hogere leidinggevende functies (excl. openbaar bestuur)

5. (19) Diverse wetenschappelijke e.a. vakspecialisten

III. Gemiddeld aandeel in de werkgelegenheid van de beroepsklasse 1979 - 1985*:

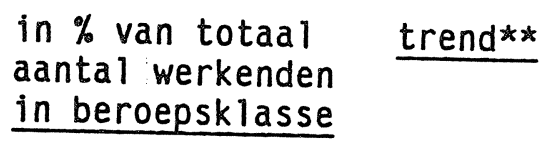

1.(06) Genees- en tandheelkundigen, dierenartsen, verplegenden en verwante vakspecialisten

in $\%$ van aantal trend** univ. geschoolden in beroepsklasse

1. (06) Genees- en tandheelkundigen, dierenartsen, verplegenden en verwante vakspecialisten 
IV. Werkloosheid:

\begin{tabular}{llll}
$\begin{array}{l}\text { \% werkloos- } \\
\text { heid 1985 } 1985\end{array}$ & $\begin{array}{l}\text { trend } \\
\star \star \star\end{array}$ & $\begin{array}{c}\text { aandeel } \\
\text { werkl. } \\
\text { nieuwk. }\end{array}$ & $\begin{array}{r}\text { aandeel } \\
\text { langd. }\end{array}$ \\
\hline
\end{tabular}

$\begin{array}{llllll}\text { - Totaal farmacologie } & 4 & 0.6 & 53\end{array}$

- Belangrijkste beroepen van inschrijuing: $\quad(\%)$

- scheikundigen. 74

- wetenschappelijk geneeskundigen 14

- Werkloosheid relatief hoog in provincies: Groningen en Utrecht.

\section{INDICATOREN}

HG-ratio kwalificatie trend**

Beroepenspreiding:

(gemiddelde $1979-1985^{*}$ )

$0.51 \quad$ gemidde $1 d$ 
AANVULLENDE GEGEVENS

Aantal werkzame apothekers 4 ) in Nederland (1 januari 1987): 2059

Werkterreinen:

\%

Beherend apothekers

52

Tweede apotheker

Apotheker in ziekenhuis

Apotheker in industrie

Apotheker elders werkzaam

15

11

8

19

Bron: Ledenadministratie KNMP

${ }^{4}$ Doctorandi in de Farmacologie met een apothekersopleiding. 
ECONOMISCHE WETENSCHAPPEN EN BEDRIJFSKUNDE (DRS.)

Code (s): 661

HISTORISCHE DATA

trend**

I. Gemiddeld aantal werkenden 1979 - 1985*:

- absoluut aantal:

- in \% van het totaal aantal werkenden:

- in $\%$ van het totaal aantal werkenden met een universitaire opleiding :

20.500

$\begin{array}{ll}0.41 & + \\ 9.9 & 0\end{array}$

II. Belangrijkste beroepsklassen warin men werkzaam is: (gemiddeld percentage $1979-1985 *$ )

1. (09) Economen

\% $\quad \underline{\text { trend** }}$

2. (21) Beleidvoerende en hogere leidinggevende functies (excl. openbaar bestuur)

$w_{0} v$. (219) diverse hogere leidinggevende functies

(211) directeuren NV, BV, stichtingen

3. (11) Accountants overheidsbedrijuen e.d.

4. (13) Leerkrachten

5. (33) Bankemployés, lokettisten e.d.

6. (02) Architecten, ingenieurs en verwante technici

7. (31) Uitvoerende hoofdambtenaren

8. (40) Directeuren en bedrijfsleiders groothande 1

9. (08) Statistici, wiskundigen, systeemanalisten en verwante vakspecialisten

10. (19) Diverse wetenschappelijke e.a. vakspecialisten

11. (39) Diverse administratieve functies 
III. Gemiddeld aandeel in de werkgelegenheid van de beroepsklasse 1979 - 1985*:

\section{in $\%$ van totaal trend** aantal werkenden in beroepsklasse}

1. (09) Economen

2. (21) Beleidvoerende en hogere leidinggevende functies (excl. openbaar bestuur)

3. (11) Accountants

4. (13) Leerkrachten

5. (33) Bankemployés, lokettisten e.d.
32

$\begin{array}{rr}3 & 0 \\ 30 & + \\ 1 & 0 \\ 1 & +\end{array}$

\section{in $\%$ van aantal trend** univ. geschoolden in beroepsklasse}

1. (09) Economen

2. (21) Beleidvoerende en hogere leidinggevende functies (excl. openbaar bestuur)

3. (11) Accountants

4. (13) Leerkrachten

5. (33) Bankemployés, lokettisten e.d.
76

26

88

6
46
0

0

$\overline{0}$

IV. Werkloosheid:

\begin{tabular}{|c|c|c|c|c|}
\hline $\begin{array}{l}\% \text { werkloos- } \\
\text { heid } 1985\end{array}$ & $\underset{\star \star \star \star}{\operatorname{ratio}} 1$ & $\underbrace{\text { trend }}_{\star \star}$ & $\begin{array}{l}\text { aandeel } \\
\text { werkl. } \\
\text { nieuwk. }\end{array}$ & $\begin{array}{l}\text { aandeel } \\
\text { langd. }\end{array}$ \\
\hline
\end{tabular}

- Totaal economische wetenschappen

- Algemene economie

- Bedrijfseconomie

- Economische sociologie

- Fiscale economie

- Accountancy 3

0.4

$\begin{aligned}+ & 50 \\ ++ & 48 \\ + & 50 \\ + & 43 \\ ++ & 56 \\ + & 56\end{aligned}$

- Belangrijkste beroepen van inschrijuing: (\%)

- economen

- leidinggevend personeel

- vakleraren

- Werkloosheid relatief hoog in provincies: Zuid-Holland en Noord-Brabant. 
INDICATOREN

$\underline{\text { HG-ratio }}$ kwalificatie trend**

Beroepenspreiding:

(gemiddelde 1979 - 1985*)

0.86 groot

0

\section{PROGNOSES}

Arbeidsmarktontwikkeling 1985 - 1992:

(in \% werkgelegenheid in 1985)

\% kwalificatie

Werkgelegenheidsontwikkeling

Vervangingsvraag

Totale vraag naar nieuwkomers

22 gemiddeld

13 hoog

$\frac{13}{35}$ gemiddeld

Instroom afgestudeerden

$97 \quad$ erg hoog

Indicator arbeidsmarktsituatie

voor afgestudeerden in $1992 * * * *$ :

2.9 matig arbeidsmarktperspectief

\section{TYPERING}

Momenteel is de WERKLOOSHEID onder afgestudeerden in deze studierichtingen LAAG.

Echter, voor de nabije toekomst zijn de ARBEIDSMARKTPERSPECTIEVEN maar MATIG. Weliswaar is de voorspelde WERKGELEGENHEIDSGROEI REDELIJK en de VERVANGINGSVRAAG vanwege pensionering, e.d. zelfs HOOG, maar daartegenover staat dat de INSTROOM VAN AFSTUDERENDEN op de arbeidsmarkt ERG HOOG zal zijn.

Wel blijken er op de arbeidsmarkt VEEL UITWIJKMOGELIJKHEDEN naar andere beroepen te bestaan. 
ECONOMETRIE, ACTUARIAAT EN BEDRIJFSKUNDE (IR.)

Code $(s): 662$

HISTORISCHE DATA

trend**

I. Gemiddeld aantal werkenden 1979 - 1985*:

- absoluut aantal:

- in \% van het totaal aantal werkenden:

1.800

- in $\%$ van het totaal aantal werkenden met een universitaire opleiding :

$\begin{array}{ll}0.04 & ++ \\ 0.8 & ++\end{array}$

II. Belangrijkste beroepsklassen waarin men werkzaam is: (gemiddeld percentage $1979-1985 *$ )

1. (09) Economen

2. (08) Statistici, wiskundigen, systeemanalisten en verwante vakspecialisten

$w \cdot v \cdot(082)$ hogere wiskundigen, actuarissen

(083) systeemanalisten e.a. automatiseringsdeskundigen

3. (02) Architecten, ingenieurs en verwante vakspecialisten

w.v. (028) bedrijfskundigen, e.d.

4. (21) Beleidvoerende en hogere leidinggevende functies (excl. openbaar bestuur)

5. (13) Leerkrachten

6. (19) Diverse wetenschappelijke e.a. vakspecialisten

7. (39) Diverse administratieve functies

8. (33) Bankemployés, lokettisten e.d.

$\underline{\%}$

9. (06) Genees - en tandheelkundigen, dierenartsen, verplegenden en verwante vakspecialisten 
IV. Werkloosheid:

\begin{tabular}{llll}
$\%$ werkloos- ratio 1 & $\begin{array}{l}\text { trend } \\
\text { heid } 1985\end{array}$ \\
\hline
\end{tabular}

- Totaal econometrie en actuariaat en bedrijfskunde (ir.)

- Bedrijfskunde (ir.)

3

0.4

$+$

61

39

- Belangrijkste beroepen van inschrijving:

(\%)

- economen

- leidinggevend personeel

- Werkloosheid relatief hoog in provincies: Noord-Holland en Noord-Brabant

\section{INDICATOREN}

\section{$\underline{\text { HG-ratio }}$ kwalificatie trend**}

Beroepenspreiding:

(gemiddelde $1979-1985^{*}$ ) 0.80 groot +

\section{PROGNOSES}

Arbeidsmarktontwikkeling 1985 - 1992:

(in \% werkgelegenheid in 1985)

Werkgelegenheidsontwikkeling

Vervangingsuraag

Totale vraag naar nieuwkomers

\section{$\% \quad$ kwalificatie}

Instroom afgestudeerden

62 erg hoog

$\frac{10}{72} \quad \begin{aligned} & \text { hoog } \\ & \text { erg hoog }\end{aligned}$

Indicator arbeidsmarktsituatie

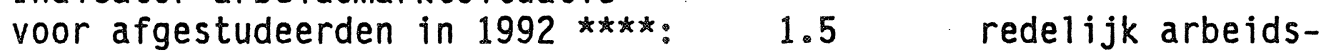
marktperspectief

\section{TYPERING}

Momenteel is de WERKLOOSHEID onder de afgestudeerden in deze studierichtingen LAAG, vergeleken met het gemiddelde van academici. Ook voor de nabije toekomst zijn de ARBEIDSMARKTPERSPECTIEVEN REDELIJK. Weliswaar is de voorspelde INSTROOM VAN AFSTUDERENDEN op de arbeidsmarkt ERG HOOG, maar daartegenover staat een ERG HOGE WERKGELEGENHEIDSGROEI en een HOGE VERVANGINGSVRAAG vanwege pensionering, e.d. Bovendien blijken er op de arbeidsmarkt VEEL UITWIJKMOGELIJKHEDEN naar andere beroepen te bestaan. 


\section{RECHTEN}

Code(s): 666

HISTORISCHE DATA

$\underline{\text { trend** }}$

I. Gemiddeld aantal werkenden 1979 - 1985*:

- absoluut aantal:

- in \% van het totaal aantal werkenden:

- in $\%$ van het totaal aantal werkenden met een universitaire opleiding :

24.100

$0.48+$
$11.6+$

II. Belangrijkste beroepsklassen waarin men werkzaam is: (gemiddeld percentage $1979-1985 *$ )

1. (12) Juristen W.v. (121) advocaten, officieren van justitie e.d.

2. (21) Beleidvoerende en hogere leidinggevende functies (excl. openbaar bestuur)

3. (31) Uitvoerende hoofdambtenaren

4. (13) Leerkrachten

5. (19) Diverse wetenschappelijke e.a. vakspecialisten

6. (39) Diverse administratieve functies

7. (20) Beleidvoerende en hogere leidinggevende functies bij openbaar bestuur

8. (33) Bankemployés, lokettisten e.d.

9. (11) Accountants

10. (32) Secretaressen, typisten en ponstypisten e.d.

$\% \quad \underline{t r e n d * *}$

$53 \quad 0$

$15 \quad 0$

$34 \quad 0$

$10 \quad 0$

$9 \quad-$

$5-0$

$\#$

$\#$

\#

$\#$

III. Gemiddeld aandeel in de werkgelegenheid van de beroepsklasse 1979 - 1985*:

in \% van totaal

$\underline{\text { trend** }}$ aantal werkenden

in beroepsklasse

1. (12) Juristen

81

0

2. (21) Beleidvoerende en hogere

leidinggevende functies

(excl. openbaar bestuur)

3. (31) Uitvoerende hoofdambtenaren

4. (13) Leerkrachten

11

0

$+$ 


\section{in $\%$ van aantal trend** univ. geschoolden \\ in beroepsklasse}

1. (12) Juristen

97

2. (21) Beleidvoerende en hogere leidinggevende functies (excl. openbaar bestuur)

3. (31) Uitvoerende hoofdambtenaren

4. (13) Leerkrachten

$\begin{array}{rr}14 & 0 \\ 43 & 0 \\ 3 & 0\end{array}$

IV. Werkloosheid:

\begin{tabular}{|c|c|c|c|c|c|}
\hline & $\begin{array}{l}\% \text { werkloos- } \\
\text { heid } 1985\end{array}$ & $\begin{array}{l}\text { ratio } 1 \\
* \star \star\end{array}$ & $\begin{array}{l}\text { trend } \\
\star \star\end{array}$ & $\begin{array}{c}\text { aandeel } \\
\text { werk } 1 . \\
\text { nieuwk. }\end{array}$ & $\begin{array}{c}\text { aandeel } \\
\text { langd. } \\
\text { werkl. }\end{array}$ \\
\hline $\begin{array}{l}\text { - Totaal rechten } \\
\text { - Nederlands recht } \\
\text { - Bedrijfsrecht } \\
\text { - Privaatrecht } \\
\text { - Publiekrecht } \\
\text { - Strafrecht } \\
\text { - Fiscaal juridisch } \\
\text { - Notariaat } \\
\text { - Vrije jurische richting }\end{array}$ & 9 & 0.8 & $\begin{array}{r}++ \\
++ \\
++ \\
++ \\
+ \\
+ \\
++ \\
+ \\
++\end{array}$ & $\begin{array}{l}59 \\
58 \\
65 \\
62 \\
60 \\
61 \\
67 \\
39 \\
50\end{array}$ & $\begin{array}{l}44 \\
40 \\
39\end{array}$ \\
\hline
\end{tabular}

- Belangrijkste beroepen van inschrijuing: - juristen

- Werkloosheid relatief hoog in provincie: Zuid-Holland

\section{INDICATOREN}

$\underline{H G-\text { ratio }}$ kwalificatie trend**

Beroepenspreiding:

(gemiddelde 1979 - 1985*)

$0.70 \quad$ gemiddeld

0

\section{PROGNOSES}

Arbeidsmarktontwikkeling 1985 - 1992:

(in \% werkgelegenheid in 1985)

Werkgelegenheidsontwikkeling

Vervangingsuraag

Totale vraag naar nieuwkomers

kwalificatie

Instroom afgestudeerden

31

$\frac{12}{43}$

hoog

hoog

hoog

Indicator arbeidsmarktsituatie voor afgestudeerden in 1992 **** :

96

erg hoog

2.4 matig arbeidsmarktperspectief 


\section{TYPERING}

Momenteel is de WERKLOOSHEID onder de afgestudeerden in deze studierichtingen GELIJK AAN HET GEMIDDELD voor academici. Voor de nabije toekomst zijn de ARBEIDSMARKTPERSPECTIEVEN maar MATIG. Weliswaar is de voorspelde WERKGELEGENHEIDSGROEI HOOG, evenals de VERVANGINGSVRAAG vanwege pensionering, e.d., maar daartegenover staat dat de INSTROOM VAN AFSTUDERENDEN op de arbeidsmarkt ERG HOOG zal zijn.

Wel blijken er op de arbeidsmarkt ENIGE UITWIJKMOGELIJKHEDEN naar andere beroepen te bestaan. 
SOCIAAL-CULTURELE WETENSCHAPPEN

Code(s): 671

HISTORISCHE DATA

trend**

I. Gemiddeld aantal werkenden 1979 - 1985*:

- absoluut aantal:

- in $\%$ van het totaal aantal werkenden:

- in \% van het totaal aantal werkenden met een universitaire opleiding :

29.900

$0.59++$
$14.2+$

II. Belangrijkste beroepsklassen waarin men werkzaam is:

(gemiddeld percentage $1979-1985{ }^{\star}$ )

\% $\quad$ trenid**

1. (19) Diverse wetenschappelijk e.a. vakspecialisten

w.v. (192) sociologen, psychologen, e.d.

(193) maatschappelijke en culturele werkers

2. (13) Leerkrachten

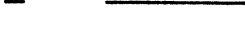

3. (21) Beleidvoerende en hogere leidinggevende functies (excl. openbaar bestuur)

4. (31) Uitvoerende hoofdambtenaren

5. (39) Diverse administratieve functies

6. (02) Architecten, ingenieurs en verwante functies

7. (15) Auteurs, journalisten e.d.

8. (06) Genees-, tandheelkundigen, dierenartsen,

9. (09) Economen verplegenden en verwante vakspecialisten

III. Gemiddeld aandeel in de werkgelegenheid van de beroepsklasse 1979 - 1985*:

\section{in $\%$ van totaal aantal werkenden in beroepsklasse}

$\underline{\text { trend** }}$

1. (19) Diverse wetenschappelijke

2. (13) Leerkrachten

3. (21) Beleidvoerende en hogere leidinggevende functies (excl. openbaar bestuur) 

in $\%$ van aantal trend** univ. geschoolden
in beroepsklasse

1. (19) Diverse wetenschappelijke

$$
\text { e.a. vakspecialisten }
$$

2. (13) Leerkrachten

63

15

10 leidinggevende functies (excl. (excl. Openbaar bestuur)

$\begin{array}{rr}63 & 0 \\ 15 & ++ \\ 10 & 0\end{array}$

IV. Werkloosheid:

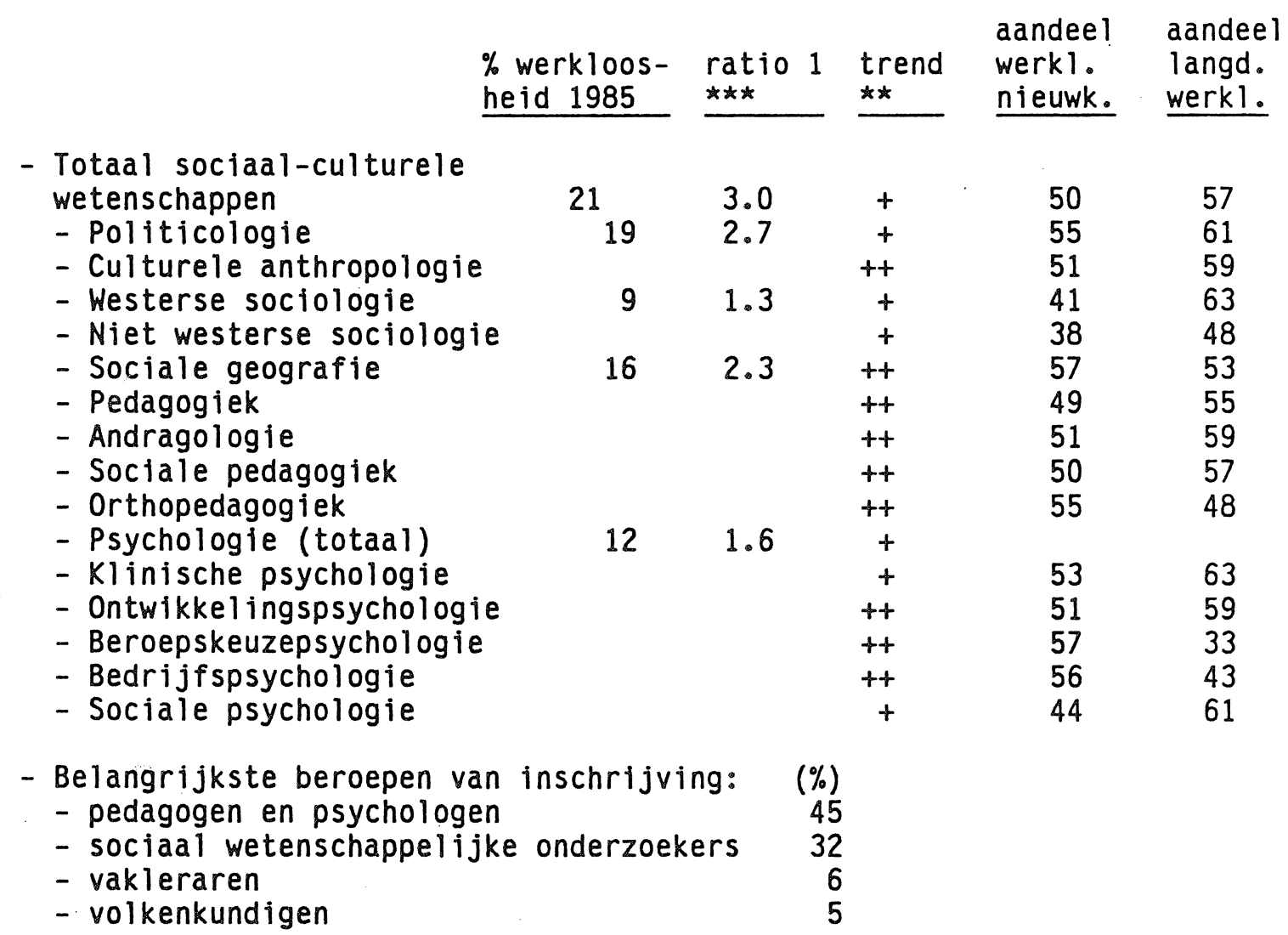

\section{INDICATOREN}

HG-ratio kwalificatie trend**

Beroepenspreiding:

(gemiddelde 1979 - $1985^{\star}$ ) 0.66 gemiddeld + 


\section{PROGNOSES}

Arbeidsmarktontwikkeling 1985 - 1992:

(in \% werkgelegenheid in 1985)

\begin{tabular}{|c|c|c|}
\hline & $\underline{\%}$ & kwalificatie \\
\hline $\begin{array}{l}\text { Werkgel egenheidsontwikkeling } \\
\text { Vervangingsvraag } \\
\text { Totale vraag naar nieuwkomers }\end{array}$ & $\begin{array}{r}32 \\
8 \\
40\end{array}$ & $\begin{array}{l}\text { hoog } \\
\text { gemidde 1d } \\
\text { hoog }\end{array}$ \\
\hline Instroom afgestudeerden & 91 & erg hoog \\
\hline $\begin{array}{l}\text { Indicator arbeidsmarktsituatie } \\
\text { voor afgestudeerden in } 19922_{\star * * *} \\
\text { TYPERING }\end{array}$ & 2.8 & $\begin{array}{l}\text { matig arbeids- } \\
\text { marktperspectief }\end{array}$ \\
\hline
\end{tabular}

Momenteel is de WERKLOOSHEID onder de afgestudeerden in deze studierichting ERG HOOG, vergeleken met het gemiddelde van academici. Ook voor de nabije toekomst zijn de ARBEIDSMARKTPERSPECTIEVEN maar matig. Weliswaar is de voorspelde WERKGELEGENHEIDSGROEI HOOG en de VERVANGINGSVRAAG vanwege pensionering, e.d., REDELIJK, maar daar staat tegenover dat de INSTROOM VAN AFSTUDERENDEN op de arbeidsmarkt erg hoog zal zijn.

Wel blijken er op de de arbeidsmarkt ENIGE UITWIJKMOGELIJKHEDEN naar andere beroepen te bestaan.

\section{AANVULLENDE GEGEVENS}

Functies van pas-afgestudeerde politicologen aan de Universiteit van Amsterdam (1975-1982):

- leraar/docent

- universitair medewerker

- overige functies in onderwijs of vormingswerk

- research medewerker

- beleidsmedewerker

- coördinator/directeur/hoofd afdeling

- voorlichter/PR-medewerker

- organisatie-adviseur

- politieke functies

- diplomaat

- journalist

Bron: De Heide, 1982 
KUNSTONDERWIJS

Code(s): 686

HISTORISCHE DATA

I. Gemiddeld aantal werkenden 1979 - 1985*:

- absoluut aantal:

- in \% van het totaal aantal werkenden:

1.600

- in $\%$ van het totaal aantal werkenden met een universitaire opleiding :

$0.03+$

0.8

II. Belangrijkste beroepsklassen waarin men werkzaam is: (gemiddeld percentage $1979-1985 *$ )

1. (19) Diverse wetenschappelijke e.a. vakspecialisten

w.v. (191) bibliothecarissen, archivarissen, e.d. (192) socjologen, psychologen, e.d.

2. (13) Leerkrachten

3. (16) Kunstschilders, fotografen e.a. beeldende kunstenaars

4. (17) Musici, toneelspelers e.a. uitvoerende kunstenaars

5. (15) Auteurs, journalisten e.d.

6. (39) Diverse administratieve functies

7. (59) Diverse dienstverlenende functies

8. (55) Huisbewaarders, schoonmaakpersoneel

9. (20) Beleidvoerende en hogere leidinggevende functies bij openbaar bestuur

10. (31) Uitvoerende hoofdambtenaren

11. (47) Verzekeringsagenten, makelaars, vellinghouders e.d.

12. (42) Zelfstandige groothandelaren en tussenpersonen

13. (43) Zelfstandige winkeliers

14. (21) Beleidvoerende en hogere leidinggevende functies (excl. openbaar bestuur) 
IV. Werkloosheid:

\begin{tabular}{|c|c|c|c|c|c|}
\hline & $\begin{array}{l}\% \text { werkloos- } \\
\text { heid } 1985\end{array}$ & $\begin{array}{l}\text { ratio } 1 \\
\star \star \star \star\end{array}$ & $\begin{array}{l}\text { trend } \\
\star \star \star \\
\end{array}$ & $\begin{array}{l}\text { aandee } 1 \\
\text { werk 1. } \\
\text { nieuwk. }\end{array}$ & $\begin{array}{l}\text { aandeel } \\
\text { langd. } \\
\text { werkl. }\end{array}$ \\
\hline $\begin{array}{l}\text { - Totaal kunstonderwijs } \\
\text { - Muziekwetenschappen } \\
\text { - Kunstwetenschappen } \\
\text { - Theaterwetenschappen }\end{array}$ & 28 & 4.0 & $\begin{array}{l}++ \\
++ \\
++ \\
++\end{array}$ & $\begin{array}{l}61 \\
58 \\
63 \\
53\end{array}$ & $\begin{array}{l}55 \\
54 \\
57 \\
50\end{array}$ \\
\hline $\begin{array}{l}\text { - Belangrijkste beroepen } \\
\text { - geschiedkundigen } \\
\text { - vakleraren } \\
\text { - auteurs } \\
\text { - regisseurs }\end{array}$ & van inschrij & $\begin{array}{r}(\%) \\
68 \\
8 \\
6 \\
6\end{array}$ & & & \\
\hline
\end{tabular}

\section{INDICATOREN}

$\underline{\text { HG-ratio kwalificatie trend** }}$

Beroepenspreiding:

(gemidde1de 1979 - 1985*)

\section{PROGNOSES}

Arbeidsmarktontwikkeling 1985 - 1992:

(in \% werkgelegenheid in 1985)

Werkge legenheidsontwikkeling

Vervangingsuraag

Totale vraag naar nieuwkomers

0.79 groot

Instroom afgestudeerden

\% kwalificatie

Indicator arbeidsmarktsituatie

voor afgestudeerden in $1992 * * * *$ : 11.0

$15 \quad 1 \mathrm{aag}$

$\frac{7}{23} \quad$ laag

$\overline{23} \quad$ laag

224 erg hoog

11.0 erg slecht arbeidsmarktperspectief

\section{TYPERING}

Momenteel is de WERKLOOSHEID onder de afgestudeerden in deze studierichtingen ERG HOOG, vergeleken met het gemiddelde van academici. ook voor de nabije toekomst zijn de ARBEIDSMARKTPERSPECTIEVEN ERG SLECHT, als gevolg van een LAGE WERKGELEGENHEIDSGROEI en een LAGE VERVANGINGSVRAAG vanwege pensioenering, e.d., terwijl bovendien de AFSTUDERENDEN op de arbeidsmarkt ERG HOOG zal zijn. Wel blijken er op de arbeidsmarkt VEEL UITWIJKMOGELIJKHEDEN naar andere beroepen te bestaan. 
MO-B AKTEN

Code (s): 606

HISTORISCHE DATA

trend**

I. Gemiddeld aantal werkenden 1979 - 1985*:

- absoluut aantal:

12.600

- in \% van het totaal aantal werkenden:

- in $\%$ van het totaal aantal werkenden met een universitaire opleiding :

$\begin{array}{ll}0.25 & + \\ 2.4 & 0\end{array}$

II. Belangrijkste beroepsklassen waarin men werkzaam is:

(gemiddeld percentage $1979-1985 *$ )

1. (13) Leerkrachten

w.v. directeuren van scholen e.a onderwijskundige functies

2. (19) Diverse wetenschappelijke e.a. vakspecialisten

3. (17) Uitvoerende kunstenaars

4. (21) Beleidvoerende en hogere leidinggevende functies (excl. openbaar bestuur)

$\begin{array}{cc}\% & \text { trend** } \\ 86 & 0 \\ 9 & + \\ \# & \\ \# & \\ \# & \end{array}$

III. Gemiddeld aandeel in de werkgelegenheid van de beroepsklasse 1979 - 1985*:

in \% van totaal trend**
aantal werkenden
in beroepsklasse

1. (13) Leerkrachten

4

0

in $\%$ van aantal trend** univ. geschoolden

in beroepsklasse

23

0

\section{INDICATOREN}

HG-ratio kwalificatie trend**

Beroepenspreiding:

(gemiddelde 1979 - 1985*)

$0.26 \quad k l e i n$

0 


\section{PROGNOSES}

Arbeidsmarktontwikkeling 1985 - 1992:

(in \% werkgelegenheid in 1985)

\%

kwalificatie

Werkgelegenheidsontwikkeling

31

hoog

Vervangingsvraag

laag

Totale vraag naar nieuwkomers

$\frac{6}{36}$

gemidde 1d 
BIJLAGE II: ARBEIDSMARKTDATA BEROEPSKLASSEN EN

ENKELE SPECIFIEKE BEROEPSGROEPEN

Bron: ROA 


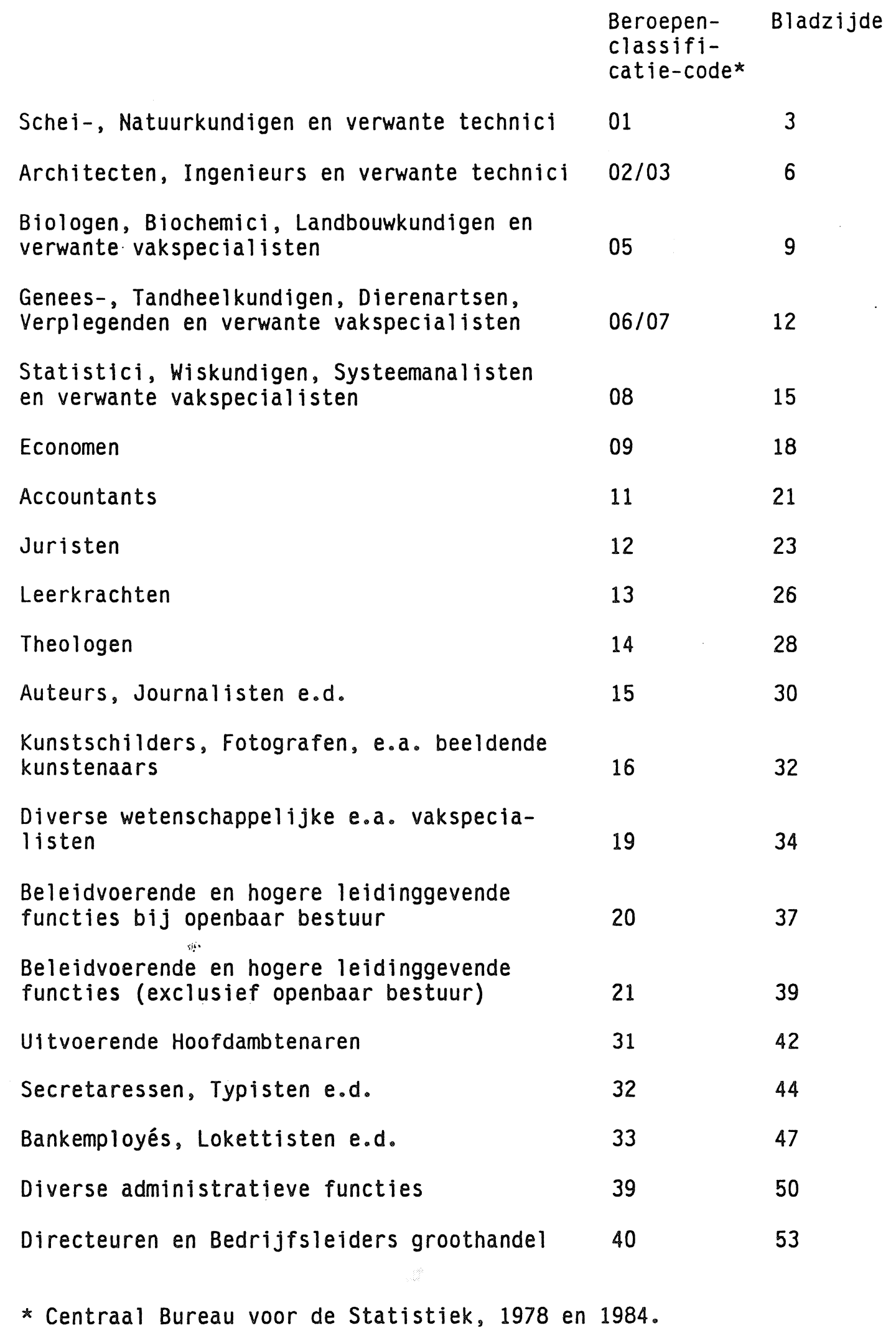




\section{VERKLARING VAN DE GEBRUIKTE TEKENS}

* Gemiddelde op basis van de jaren 1979, 1981, 1983 en 1985.

** Op basis van een vergelijking tussen de jaren 1983 en 1985 ten opzichte van de jaren 1979 en 1981.

$$
\begin{aligned}
++ & =\text { sterk stijgend } \\
+ & =\text { stijgend } \\
0 & =\text { constant } \\
- & =\text { dalend } \\
- & =\text { sterk dalend }
\end{aligned}
$$

Voor de hierbij gehanteerde classificatiecriteria zie bijlage III.

\# Te gering percentage of aantal (zie paragraaf 2.2 ). 
SCHEI -, NATUURKUNDIGEN EN VERWANTE TECHNICI

Code: 01

HISTORISCHE DATA

trend $\star \star$

I. Gemiddeld aantal werkenden 1979-1985*: 33.200

Gemiddeld \% van het totaal aantal

0.67

0

Gemiddeld aantal werkenden 1979 - 1985* in enkele specifieke beroepsgroepen:

- Scheikundigen (code 011): 2.800

- gemiddeld \% van het totaal aantal werkenden:

0.06

- Natuurkundigen (drs/ir) (code 012): 1.700

- gemiddeld \% van het totaal aantal werkenden:

- Geologen, meteorologen e.d. (code 013):

- gemiddeld \% van het totaal aantal werkenden:

$0.02+$

II. Aandeel leeftijdsgroepen:

(gemiddeld percentage 1979 - 1985*)

$<30$ jaar
$30-49$ jaar
$50-59$ jaar
$60-64$ jaar

trend $* *$

37

48

13

0

0

\# 
III. Aandeel opleidingscategorieën:

(gemiddeld percentage 1979 - 1985*)

$\begin{array}{lcc} & \underline{\%} & \text { trend } \star \star \\ \text { Universitair opgeleiden } & 16 & -- \\ \text { HBO-ers } & 30 & + \\ \text { MBO-ers } & 28 & + \\ \text { LBO-ers } & 7 & + \\ \text { HAVO/VWO-ers } & \# & - \\ \text { MAVO-ers } & 6 & \\ \text { Basis onderwijs } & \# & \end{array}$

IV. Belangrijkste bedrijfsklassen waarin men werkzaam is: (gemiddeld percentage 1979 - 1985*)

1. (20-22) Kwartaire sector

$$
\begin{array}{ll}
\text { w.v. } & \text { (22) Overheid } \\
& \text { (20) Medische en } \\
\text { veterinaire diensten }
\end{array}
$$

2. (2-12) Industrie en openbare nutsbedrijven

$w \cdot v \cdot$
(6) Chemische, rubber- en kunsts tofverwerkende industrie
(2) Voedings - en genot- midde lenindustrie

45

22

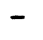

$+$

5

$+$

3. (14-19) Commerciële diensten

45

$\begin{array}{ll}20 & - \\ 8^{9} & +\end{array}$

\section{$\underline{\%}$}

V. Aandeel zelfstandigen (gemiddeld percentage $\left.1979-1985^{*}\right)$ :

0.1 
INDICATOREN

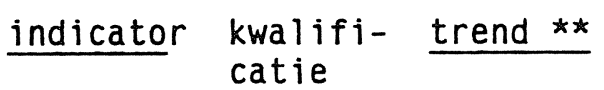

Vervangingsbehoefte ouderen

- Gemiddelde van 1979 - 1985*

1.12 groot $\quad+$

Absorptiegraad < 30 jarigen

- Gemiddelde van 1979 - 1985*

1.25 groot 0

Branchespreiding

- Gemiddelde van 1979 - 1985*:

0.90 groot 0

Conjunctuurgevoeligheid

- Periode 1950 - 1985:

$13.2 \%$ gemiddeld

\section{PROGNOSES}

Arbeidsmarktontwikkel ingen 1985 - 1992:

(in \% van werkgelegenheid in 1985)

\% $\quad$ kwalificatie

Werkgelegenheidsontwikkeling

8 gemiddeld

Vervangingsvraag

$16 \quad$ laag

Totale vraag naar nieuwkomers

24 gemiddeld

Vraag naar schoolverlaters

$16 \quad$ gemiddeld

\section{TYPERING}

Redelijk werkgelegenheidsperspectief, weinig conjunctuurgevoelig en er zijn ook goede uitwijkmogelijkheden. 
ARCHITECTEN, INGENIEURS EN VERWANTE TECHNICI

Code: $02 / 03$

HISTORISCHE DATA

trend $* *$

I. Gemiddeld aantal werkenden 1979-1985*: 175.700

Gemiddeld \% van het totaal aantal

werkenden 1979 - 1985*:

Gemiddeld aantal werkenden 1979 - 1985* in enkele specifieke beroepsgroepen.

- Architecten, stedebouwkundigen (code 021):

5.900

- gemiddeld \% van het totaal aantal werkenden:

0.12

0

- Hoofden technische dienst (hoger) (code 024):

2.400

- gemiddeld \% van het totaal aantal werkenden:

$0.05+$

- Hogere chemisch technologen (code 026):

- gemiddeld \% van het totaal aantal werkenden:

4.100

- Hogere technisch natuurkundigen en metaalkundigen (code 027):

- gemiddeld \% van het totaal aantal werkenden:

0

- Hogere technici, specialisaties n.e.g. (code 029):

- gemiddeld \% van het totaal aantal werkenden:

0.19

$++$

II. Aandeel leeftijdgroepen:

(gemiddeld percentage 1979 - 1985*)

30 - 49 jaar

50 - 59 jaar 
III. Aandeel opleidingscategorieën:

(gemiddeld percentage 1979 - 1985*)

$\begin{array}{lcc} & \% & \text { trend } \star \star \\ \text { Universitair opgeleiden } & 12 & ++ \\ \text { HBO-ers } & 32 & 0 \\ \text { MBO-ers } & 45 & 0 \\ \text { LBO-ers } & 6 & 0 \\ \text { HAVO/VWO-ers } & \# & \\ \text { MAVO-ers } & \# & \#\end{array}$

IV. Belangrijkste bedrijfsklassen waarin men werkzaam is: (gemiddeld percentage 1979 - 1985*)

1. (2-12) Industrie en openbare nutsbedrijven

36
W.v. (7/8) Basismetaal, metaal-
produkten- en optische industrie

(9) Electrotechnische industrie

2. (14-19) Commerciële diensten

3. (20-22) Kwartaire sector w.v. (22) Overheid

4. (13) Bouwnijverheid

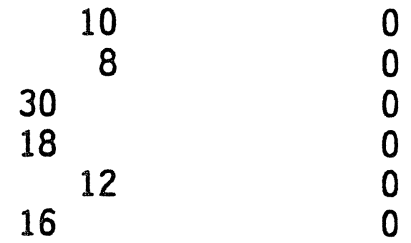

v. Aandeel zelfstandigen:

(gemiddeld percentage 1979 - 1985*)

\section{INDICATOREN}

Vervangingsbehoefte ouderen

- Gemiddelde van 1979-1985*:

Absorptiegraad < 30 jarigen

- Gemiddelde van 1979 - 1985*:

Branchespreiding

- Gemiddelde van 1979 - 1985*:

Conjunctuurgevoel ighe id

- Periode 1950 - 1985:

\section{indicator kwalifi- trend **} catie

1.41 groot

0

$0.79 \quad k l e i n$

0.92 groot

0

$14.9 \%$ gemiddeld 


\section{PROGNOSES}

Arbeidsmarktontwikkeling 1985 - 1992:

(in \% van werkgelegenheid in 1985)

$\begin{aligned} \underline{\%} & \text { kwalificatie } \\ 12 & \text { hoog } \\ \frac{12}{25} & \text { laag } \\ 20 & \text { gemiddeld } \\ & \text { hoog }\end{aligned}$

TYPERING

Redelijk werkgelegenheidsperspectief, weinig conjunctuurgevoelig en er zijn ook goede uitwijkmogelijkheden. 
BIOLOGEN, BIOCHEMICI, LANDBOUWKUNDIGEN EN VERWANTE VAKSPECIALISTEN

\section{Code: 05}

HISTORISCHE DATA

trend $\star \star$

I. Gemiddeld aantal werkenden 1979-1985*: 25.400

Gemiddeld \% van het totaal aantal

werkenden 1979 - 1985*:

0.50

Gemiddeld aantal werkenden 1979 - 1985* in enkele specifieke beroepsgroepen.

- Biologen, zoölogen, botanici e.d.

(code 051):

2.000

- gemiddeld \% van het totaal aantal werkenden:

0.04

- Hogere biochemici, bacteriologen, farmacologen e.d. (code 052):

- gemiddeld \% van het totaal aantal werkenden:

- Hogere landbouwkundigen (code 053):

3.000

- gemiddeld \% van het totaal aantal werkenden:

0.08

II. Aandeel leeftijdgroepen:

(gemiddeld percentage 1979 - 1985*)

trend $* *$

30 jaar
$30-49$ jaar
$50-59$ jaar
$60-64$ jaar

43

45

0

0

9

0 
III. Aandeel opleidingscategorieën:

(gemiddeld percentage 1979 - 1985*)

\begin{tabular}{llc} 
& \multicolumn{1}{c}{$\%$} & trend ** \\
\cline { 2 - 2 } Universitair opgeleiden & 23 & - \\
HBO-ers & 44 & 0 \\
MBO-ers & 24 & 0 \\
LBO-ers & $\#$ & \\
HAVO/VWO-ers & $\#$ & \\
MAVO-ers & $\#$ & \\
Basis onderwijs & $\#$ &
\end{tabular}

IV. Belangrijkste bedrijfsklassen waarin men werkzaam is: (gemiddeld percentage 1979 - 1985*)

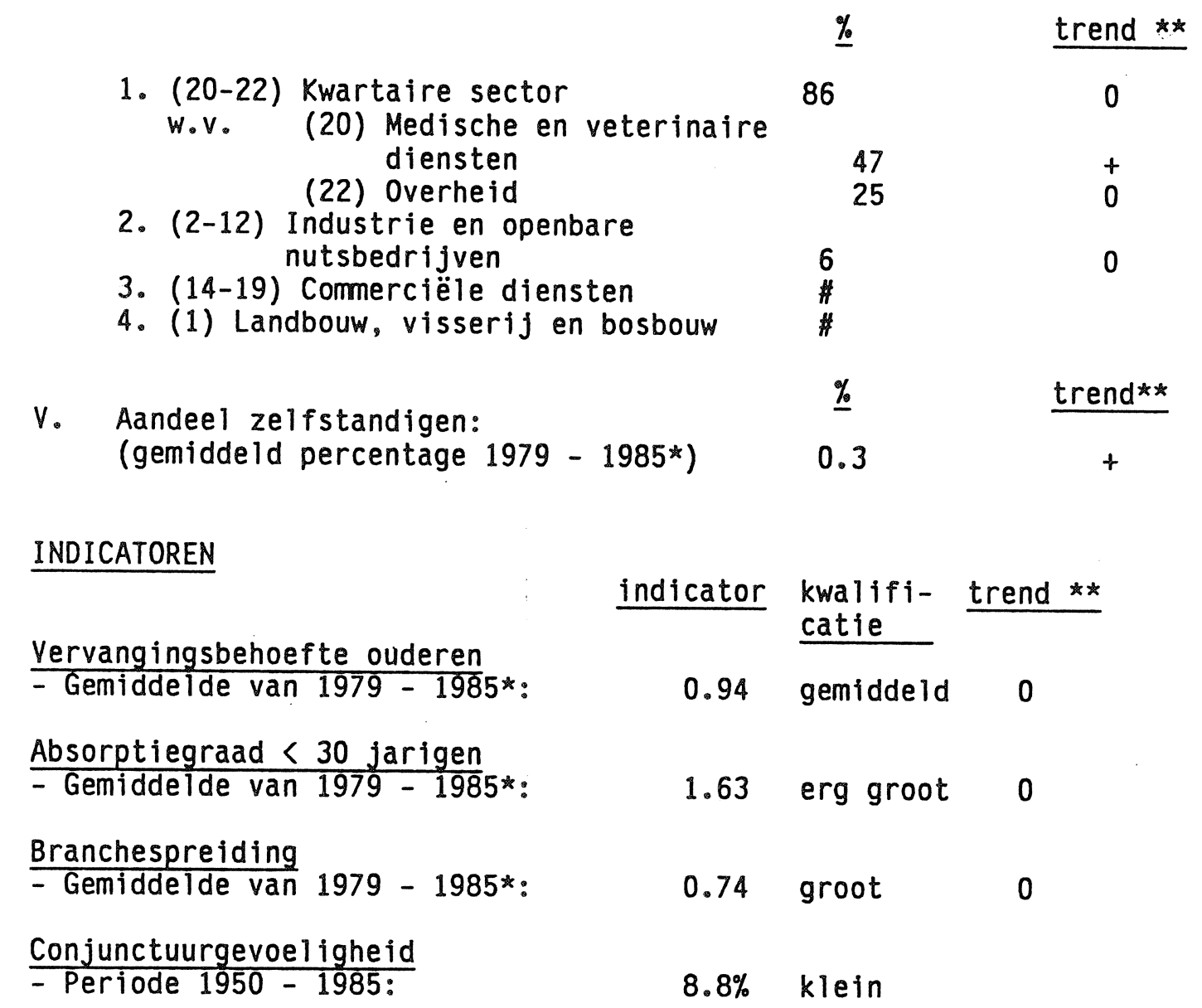


PROGNOSES

Arbeidsmarktontwikkeling 1985 - 1992:

(in \% van werkgelegenheid in 1985)

\% $\quad$ kwalificatie

Werkgel egenheidsontwikkeling

16 hoog

Vervangingsuraag

Totale vraag naar nieuwkomers

9 erg laag

25 gemiddeld

Vraag naar schoolverlaters

2

erg laag

\section{TYPERING}

Redelijk werkgelegenheidsperspectief, weinig conjunctuurgevoelig en er zijn ook goede uitwijkmogelijkheden. 
GENEES-, TANDHEELKUNDIGEN, DIERENARTSEN, VERPLEGENDEN EN VERWANTE VAKSPECIALISTEN

Code: $06 / 07$

\section{HISTORISCHE DATA}

trend $\star \star$

I. Gemiddeld aantal werkenden 1979-1985*: 237.100

Gemiddeld \% van totaal aantal

werkenden 1979 - 1985*:

4.70

$++$

Gemiddeld aantal werkenden 1979 - 1985* in enkele specifieke beroepsgroepen.

- Geneeskundigen (code 061):

22.600

- gemiddeld \% van het totaal aantal werkenden:

$0.45+$

- Tandheelkundigen (code 063):

- gemiddeld \% van het totaal aantal werkenden:

4.900

Diergeneeskundigen (code 065):

- gemiddeld \% van het totaal aantal werkenden:

$0.04 \quad 0$

- Apothekers (code 067):

- gemiddeld \% van het totaal aantal werkenden:

1.300

0.03

$+$

II. Aandeel leeftijdgroepen:

(gemiddeld percentage 1979 - 1985*)

$<30$ jaar

55

30 - 49 jaar

50 - 59 jaar

60 - 64 jaar

36

7 
III. Aandeel opleidingscategorieën:

(gemiddeld percentage $1979-1985^{\star}$ )

$\begin{array}{lcc} & \% & \text { trend } \star \star \\ \text { Universitair opgeleiden } & 13 & - \\ \text { HBO-ers } & 17 & ++ \\ \text { MBO-ers } & 55 & 0 \\ \text { LBO-ers } & \# & - \\ \text { HAVO/VWO-ers } & 6 & \\ \text { MAVO-ers } & \# & \\ \text { Basis onderwijs } & \# & \end{array}$

IV. Belangrijkste bedrijfsklassen waarin men werkzaam is: (gemiddeld percentage 1979 - 1985*)

V. Aandeel zelfstandigen:

(gemiddeld percentage $1979-1985^{*}$ ) 12.0

1. (20-22) Kwartaire sector W.V.

(20) Medische en veterinaire diensten

2. (14-19) Commerciële diensten

INDICATOREN

Vervangingsbehoefte ouderen

- Gemiddelde van 1979-1985*:

Absorptiegraad < 30 jarigen

- Gemiddelde van 1979-1985*:

Branchespreiding

- Gemiddelde van 1979 - 1985*:

Conjunctuurgevoeligheid

- Periode 1950 - 1985:
\%

94

trend $\star \star$

0

53

\%

trend $\star \star$

0 indicator kwalifi- trend **

catie

0.83 klein $\quad+$

1.81 erg groot 0

$0.30 \quad$ klein

$9.2 \% \quad k l e i n$ 
PROGNOSES

Arbeidsmarktontwikkeling 1985 - 1992:

(in \% van werkgelegenheid in 1985)

Werkgelegenheidsontwikkeling

$\underline{\%}$

kwalificatie

Vervangingsuraag

Totale vraag naar nieuwkomers

14 hoog

$\frac{10}{25} \quad$ laag

25 gemiddeld

Vraag naar schoolverlaters

15

gemidde ld

TYPERING

Redelijk werkgelegenheidsperspectief, weinig conjunctuurgevoelig, maar er zijn ook weinig uitwijkmogelijkheden. 
STATISTICI, WISKUNDIGEN, SYSTEEMANALISTEN EN VERWANTE VAKSPECIALISTEN

Code: 08

HISTORISCHE DATA

trend $* *$

I. Gemiddeld aantal werkenden 1979-1985*: 40.000

Gemiddeld \% van het totaal aantal

werkenden 1979 - 1985*:

0.79

$++$

Gemiddeld aantal werkenden 1979 - 1985* in enkele specifieke beroepsgroepen.

- Hogere statistici (code 081): $\quad 400$

- gemiddeld \% van het totaal aantal werkenden:

$+$

- Wiskundigen, actuarissen (code 082): 1.000

- gemiddeld \% van het totaal aantal werkenden:

0.02

II. Aandeel leeftijdgroepen:

(gemiddeld percentage $1979-1985^{\star}$ )

\begin{tabular}{|c|c|c|}
\hline & $\%$ & 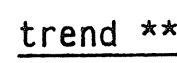 \\
\hline $\begin{array}{l}<30 \text { jaar } \\
30-49 \text { jaar } \\
50-59 \text { jaar } \\
60-64 \text { jaar }\end{array}$ & $\begin{array}{r}37 \\
57 \\
\# \\
\#\end{array}$ & $\begin{array}{l}0 \\
0\end{array}$ \\
\hline
\end{tabular}

III. Aandeel opleidingscategorieën:

(gemiddeld percentage 1979 - 1985*)

$\begin{array}{lrc} & \% & \text { trend ** } \\ \text { Universitair opgeleiden } & 10 & - \\ \text { HBO-ers } & 32 & 0 \\ \text { MBO-ers } & 32 & 0 \\ \text { LBO-ers } & \# & 0 \\ \text { HAVO/VWO-ers } & 14 & - \\ \text { MAVO-ers } & 5 & \\ \text { Basis onderwijs } & \# & \end{array}$


IV. Belangrijkste bedrijfsklassen waarin men werkzaam is: (gemiddeld percentage 1979 - 1985*)

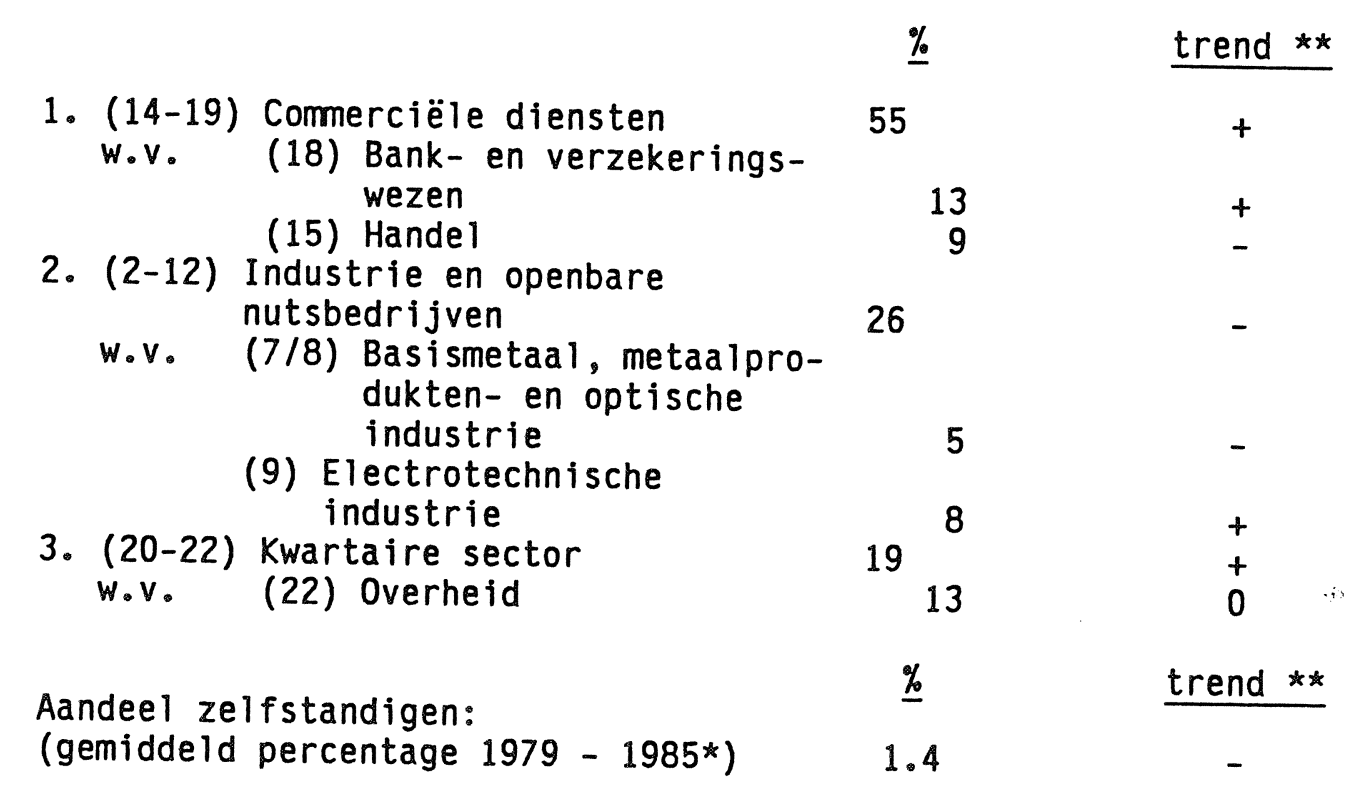

INDICATOREN

Vervangingsbehoefte ouderen

\section{indicator kwalifi- trend ** \\ catie}

0.87 klein ++

Absorptiegraad $<30$ jarigen

- Gemiddelde van 1979-1985*:

1.25 groot 0

Branchespreiding

- Gemiddelde van 1979 - 1985*:

0.90 groot $\quad 0$

Conjunctuurgevoeligheid

- Periode 1950 - 1985:

$11.1 \%$ gemiddeld 


\section{PROGNOSES}

Arbeidsmarktontwikkeling 1985 - 1992:

(in \% van werkgelegenheid in 1985)

$\% \quad$ kwalificatie

Werkgelegenheidsontwikkeling

57 erg hoog

Vervangingsuraag

Totale vraag naar nieuwkomers

3 erg laag

$\frac{3}{60} \quad$ erg hoog

Vraag naar schoolverlaters

23 hoog

\section{TYPERING}

Goed werkgelegenheidsperspectief, weinig conjunctuurgevoelig, er zijn ook goede uitwijkmogelijkheden. 


\section{ECONOMEN}

Code: 09

\section{HISTORISCHE DATA}

trend $* *$

I. Gemiddeld aantal werkenden 1979-1985*: 13.700

Gemiddeld \% van het totaal aantal

werkenden 1979 - 1985*:

0.27

$+$

II. Aandeel leeftijdgroepen:

(gemiddeld percentage $1979-1985^{\star}$ )

$$
\begin{array}{ll}
30 & \text { jaar } \\
30-49 & \text { jaar } \\
50-59 & \text { jaar } \\
60-64 & \text { jaar }
\end{array}
$$

III. Aandeel opleidingscategorieën:

(gemiddeld percentage 1979 - 1985*)

Universitair opgeleiden

HBO-ers

MBO-ers

16

LBO-ers

HAVO/VWO-ers

MAVO-ers

Basis onderwijs 
IV. Belangrijkste bedrijfsklassen waarin men werkzaam is: (gemiddeld percentage 1979 - 1985*)
1. (14-19) Commerciële diensten
w.v. (18) Bank- en verzekerings- wezen
(15) Handel
2. (2-12) Industrie en openbare nutsbedrijuen
\% trend $* *$
$55+$

$\begin{array}{ll}12 & - \\ 14 & + \\ 23 & +\end{array}$
w.v. (6) Chemische, rubber - en kunsts tofverwerkende industrie
3. (20-22) Kwartaire sector w.v. (22) Overheid
4. (13) Bouwnijverheid

${ }^{18}{ }^{\#} 12$ -
V. Aandeel zelfstandigen:
(gemiddeld percentage 1979 - 1985*)

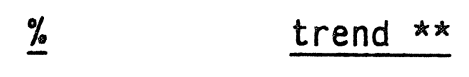
6.1

\section{INDICATOREN}

Vervangingsbehoefte ouderen

indicator kwalifi- trend **

catie

- Gemiddelde van 1979-1985*:

1.87 erg groot +

Absorptiegraad < 30 jarigen

- Gemiddelde van 1979-1985*:

0.91 gemiddeld -

Branchespreiding

- Gemiddelde van 1979 - 1985*:

0.92 groot $\quad 0$

Conjunctuurgevoeligheid

- Periode 1950 - 1985:

$10.3 \%$ gemiddeld 


\section{PROGNOSES}

Arbeidsmarktontwikkeling 1985 - 1992:

(in \% van werkgelegenheid in 1985)

\% $\quad$ kwalificatie

Werkgelegenheidsontwikkeling

Vervangingsvraag

26 erg hoog

Totale vraag naar nieuwkomers

$\frac{12}{38}$ laag

$\overline{38} \quad$ hoog

Vraag naar schoolverlaters

8

laag

\section{TYPERING}

Goed werkgelegenheidsperspectief, weinig conjunctuurgevoelig, er zijn ook goede uitwijkmogelijkheden. 


\section{ACCOUNTANTS}

Code: 11

\section{HISTORISCHE DATA}

trend $\star \star$

I. Gemiddeld aantal werkenden 1979-1985*: 13.400

Gemiddeld \% van het totaal aantal

werkenden 1979 - 1985*:

0.26

0

II. Aandeel leeftijdgroepen:

(gemiddeld percentage $1979-1985^{\star}$ )

$<30$ jaar

$30-49$ jaar

50 - 59 jaar

60 - 64 jaar

III. Aandeel opleidingscategorieën:

(gemiddeld percentage 1979 - 1985*)

Universitair opgeleiden

HBO-ers

MBO-ers

LBO-ers

HAVO/VWO-ers

MAVO-ers

Basis onderwijs $\underline{\%}$

$\underline{\%}$

11

54

22

trend $* \star$

$\overline{0}$

$+$

trend $* *$

33
31
23
$\#$
$\#$
$\#$
$\#$

IV. Belangrijkste bedrijfsklassen waarin men werkzaam is: (gemiddelld percentage $1979-1985^{\star}$ )

$\underline{\%}$

1. (14-19) Commerciële diensten

2. (20-22) Kwartaire sector w.V. (22) Overheid

3. (2-12) Industrie en openbare nutsbedrijuen

V. Aandeel zelfstandigen:

(gemiddeld percentage $1979-1985^{\star}$ )
89

$\#$

$\#$

$\underline{\%}$

39.4 trend $* *$

$+$

trend $* *$

$++$ 
INDICATOREN

Vervangingsbehoefte ouderen

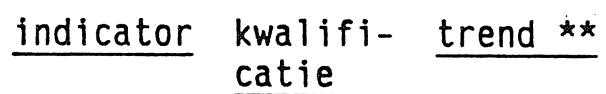

- Gemiddelde van 1979 - 1985*:

3.16 erg groot 0

Absorptiegraad $<30$ jarigen

- Gemiddelde van 1979 - 1985*:

0.44 erg klein -

Branchespreiding

- Gemiddelde van 1979 - 1985*:

0.31 gemiddeld -

Conjunctuurgevoeligheid

- Periode 1950 - 1985:

$6.3 \% \quad k l e i n$

\section{PROGNOSES}

Arbeidsmarktontwikkeling 1985 - 1992:

(in \% van werkgelegenheid in 1985)

\% $\quad$ kwalificatie

Werkgelegenheidsontwikkeling

25 erg hoog

Vervangingsvraag

16 laag

Totale vraag naar nieuwkomers

$\overline{41} \quad$ erg hoog

Vraag naar schoolverlaters

$17 \quad$ hoog

TYPERING

Goed werkgelegenheidsperspectief, weinig conjunctuurgevoelig, er zijn ook enige uitwijkmogelijkheden. 
JURISTEN

Code: 12

HISTORISCHE DATA

trend $* \star$

I. Gemiddeld aantal werkenden 1979-1985*: 15.800

Gemiddeld \% van het totaal aantal

werkenden 1979 - 1985*:

0.31

$++$

Gemiddeld aantal werkenden 1979 - 1985* in enkele specifieke beroepsgroepen.

- Advocaten, Officieren van Justitie

e.d. (code 121):

3.900

- gemiddeld \% van het totaal aantal werkenden:

0.08

- Rechters (code 122):

- gemiddeld \% van het totaal aantal werkenden:

800

0.02

II. Aandeel leeftijdgroepen:

(gemiddeld percentage 1979 - 1985*)

\%

trend $* \star$

30 jaar

30 - 49 jaar

50 - 59 jaar

60 - 64 jaar

23

60

11

III. Aandeel opleidingscategorieën:

(gemiddeld percentage 1979 - 1985*)

$\underline{\%}$

trend $* *$

Universitair opgeleiden

83

HBO-ers

8

MBO-ers

LBO-ers

HAVO/VWO-ers

MAVO-ers

Basis onderwijs

trend $* *$

80


IV. Belangrijkste bedriffsklassen waarin men werkzaam is: (gemiddeld percentage 1979 - 1985*)
1. (14-19) Commerciële diensten $w \cdot v$.
(18) Bank- en verzekerings-
2. (20-22) Kwartaire sector
W.V. (22) Overheid
3. (2-12) Industrie- en openbare nutsbedrijuen

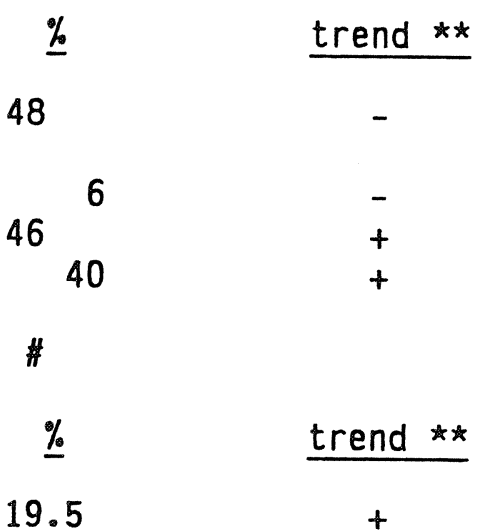
V. Aandeel zelfstandigen:
(gemiddeld percentage 1979 - 1985*)
19.5

\section{INDICATOREN}

Vervangingsbehoefte ouderen

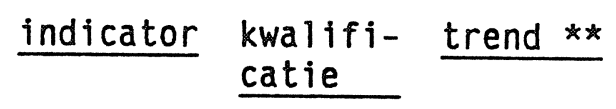

- Gemiddelde van 1979-1985*:

2.03 erg groot ++

Absorptiegraad $<30$ jarigen

- Gemiddelde van 1979-1985*:

1.10 gemiddeld -

Branchespreiding

- Gemiddelde van 1979 - 1985*:

0.71 groot 0

Conjunctuurgevoel igheid

- Periode 1950 - 1985:

$6.2 \% \quad k l e i n$

\section{PROGNOSES}

Arbeidsmarktontwikkeling 1985 - 1992:

(in \% van werkgelegenheid in 1985)

Werkgelegenheidsontwikkeling

Vervangingsvraag

Totale vraag naar nieuwkomers

kwalificatie

Vraag naar schoolverlaters 
TYPERING

Goed werkgelegenheidsperspectief, weinig conjunctuurgevoelig, er zijn ook goede uitwijkmogelijkheden. 


\section{LEERKRACHTEN}

Code: 13

HISTORISCHE DATA

trend $\star \star$

I. Gemiddeld aantal werkenden 1979-1985*: 263.300

Gemiddeld \% van het totaal aantal

werkenden 1979 - 1985*:

\subsection{2}

$+$

II. Aandeel leeftijdgroepen:

(gemiddeld percentage 1979 - 1985*)

$$
\begin{aligned}
& 30 \text { jaar } \\
& 30-49 \text { jaar } \\
& 50-59 \text { jaar } \\
& 60-64 \text { jaar }
\end{aligned}
$$

III. Aandeel opleidingscategorieën:

(gemiddeld percentage 1979 - 1985*)

Universitair opgeleiden

HBO-ers

18

MBO-ers

LBO-ers

HAVO/VWO-ers

MAVO-ers

Basis onderwijs

IV. Belangrijkste bedrijfsklassen waarin men werkzaam is: (gemiddeld percentage 1979 - 1985*)
1. (20-22) Kwartaire sector w.v. (22) Overheid
2. (14-19) Commerciële diensten
\% $\quad$ trend $* *$
$98 \quad 0$ 96
0
v. Aandeel zelfstandigen:

\% trend **
(gemiddeld percentage 1979 - 1985*)
1.0 
INDICATOREN

indicator kwalifi- trend $\star \star$

catie

Vervangingsbehoefte ouderen

- Gemiddelde van 1979 - 1985*:

1.31 groot $\quad+$

Absorptiegraad $<30$ jarigen

- Gemiddelde van 1979-1985*

1.10 gemiddeld --

Branchespreiding

- Gemiddelde van 1979 - 1985*:

$0.10 \quad k l e i n$

Conjunctuurgevoeligheid
- Periode 1950 - 1985:
$4.3 \%$ erg $k l e i n$

\section{PROGNOSES}

Arbeidsmarktontwikkeling 1985 - 1992:

(in \% van werkgelegenheid in 1985)

\% $\quad$ kwalificatie

Werkgel egenheidsontwikkeling

12 groot

Vervangingsvraag

$11 \quad$ laag

Totale vraag naar nieuwkomers

$\overline{23} \quad$ laag

Vraag naar schoolverlaters

10

laag

TYPERING

Matig werkgelegenheidsperspectief, weinig conjunctuurgevoelig, maar er zijn ook weinig uitwijkmogelijkheden. 
THEOLOGEN

Code: 14

HISTORISCHE DATA

trend $* \star$

I. Gemiddeld aantal werkenden 1979-1985*: 8.900

Gemiddeld \% van het totaal aantal

werkenden 1979 - 1985*:

0.18

$+$

II. Aandeel leeftijdgroepen:

(gemiddeld percentage $1979-1985^{\star}$ )

$\begin{array}{lcc} & \% & \text { trend } * * \\ 30 \text { jaar } & \# & \\ 30-49 \text { jaar } & 44 & - \\ 50-59 \text { jaar } & 29 & 0 \\ 60-64 \text { jaar } & 12 & +\end{array}$

III. Aandeel opleidingscategorieën:

(gemiddeld percentage 1979 - 1985*)

\begin{tabular}{|c|c|c|}
\hline & $\underline{\%}$ & trend ** \\
\hline $\begin{array}{l}\text { Universitair opgeleiden } \\
\text { HBO-ers } \\
\text { MBO-ers } \\
\text { LBO-ers } \\
\text { HAVO/VWO-ers } \\
\text { MAVO-ers } \\
\text { Basis onderwijs }\end{array}$ & $\begin{array}{r}49 \\
36 \\
\# \\
\# \\
\# \\
\# \\
\#\end{array}$ & $\begin{array}{l}0 \\
+\end{array}$ \\
\hline
\end{tabular}

IV. Belangrijkste bedrijfsklassen waarin men werkzaam is: (gemiddeld percentage 1979 - 1985*)
1. (20-22) Kwartaire sector veterinaire diensten
(22) Overheid
w.v. (20) Medische en
\% $\quad \underline{\text { trend ** }}$
$100 \quad 0$
V. Aandeel zelfstandigen (gemiddeld
percentage $\left.1979-1985^{*}\right)$ :

\section{$\#$}


INDICATOREN

Vervangingsbehoefte ouderen

\begin{tabular}{|c|c|c|}
\hline indicator & $\begin{array}{l}\text { kwalifi- } \\
\text { catie }\end{array}$ & trend $* x$ \\
\hline 2.25 & erg groot & ++ \\
\hline 0.32 & erg klein & ++ \\
\hline 0.21 & klein & + \\
\hline $13.1 \%$ & gemiddeld & \\
\hline
\end{tabular}

PROGNOSES

Arbeidsmarktontwikkeling 1985 - 1992:

(in \% van werkgelegenheid in 1985)

\% $\quad$ kwalificatie

Werkgelegenheidsontwikkel ing

-1 dalend

Vervangingsuraag

16 laag

Totale vraag naar nieuwkomers

$\overline{15}$ erg laag

Vraag naar schoolverlaters

0 nihil

TYPERING

Slecht werkgelegenheidsperspectief, weinig conjunctuurgevoelig, maar er zijn ook weinig uitwijkmogelijkheden. 
AUTEURS, JOURNALISTEN E.D.

Code: 15

HISTORISCHE DATA

trend $* *$

I. Gemiddeld aantal werkenden 1979-1985*: 16.800

Gemiddeld \% van het totaal aantal

werkenden 1979 - 1985*:

0.34

$+$

II. Aandeel leeftijdgroepen:

(gemiddeld percentage 1979. - 1985*)

30 jaar
$30-49$ jaar
$50-59$ jaar
$60-64$ jaar

trend $\star \star$

$25 \quad 0$

$54-0$

13

$\#$

III. Aandeel opleidingscategorieën:

(gemiddeld percentage 1979 - 1985*)

\begin{tabular}{lrc} 
& $\underline{\%}$ & trend ** \\
\cline { 2 - 2 } & 10 & + \\
Universitair opgeleiden & 32 & + \\
MBO-ers & 20 & 0 \\
LBO-ers & $\#$ & - \\
HAVO/VWO-ers & 24 & 0 \\
MAVO-ers & 7 & \\
Basis onderwijs & $\#$ &
\end{tabular}

IV. Belangrijkste bedrijfsklassen waarin men werkzaam is: (gemiddeld percentage 1979 - 1985*)

$\underline{\%}$

trend $* *$

1. (2-12) Industrie en openbare nutsbedrijven

48

W.v. (5) Papier- en grafische industrie

2. (20-22) Kwartaire sector w.v. (22) Overheid

3. (14-19) Commerciële diensten

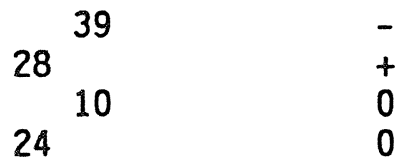


v. Aandeel zelfstandigen:

(gemiddeld percentage 1979 - 1985*)

15.7

INDICATOREN

Vervangingsbehoefte ouderen

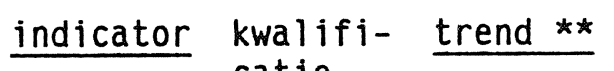
catie

2.26 erg groot +

Absorptiegraad < 30 jarigen

- Gemiddelde van 1979-1985*:

0.83 klein

0

Branchespreiding

- Gemiddelde van 1979 - 1985*:

0.81 groot

0

Conjunctuurgevoel igheid

- Periode 1950 - 1985:

$12.3 \%$ gemiddeld

\section{PROGNOSES}

Arbeidsmarktontwikkeling 1985 - 1992:

(in \% van werkgelegenheid in 1985)

\% $\quad$ kwalificatie

Werkgelegenheidsontwikkeling

Vervangingsuraag

Totale vraag naar nieuwkomers

16 hoog

6 erg laag

$\overline{22} \quad$ laag

Vraag naar schoolverlaters

0

nihil

\section{TYPERING}

Matig werkgelegenheidsperspectief, weinig conjunctuurgevoelig en er zijn ook goede uitwijkmogelijkheden. 
KUNSTSCHILDERS, FOTOGRAFEN, E.A. BEELDENDE KUNSTENAARS

Code: 16

HISTORISCHE DATA

trend $\star *$

I. Gemidde1d aantal werkenden 1979-1985*: 28.100

Gemiddeld \% van het totaal aantal

werkenden 1979 - 1985*:

0.56

0

II. Aandeel leeftijdgroepen:

(gemiddeld percentage 1979 - 1985*)

\begin{tabular}{|c|c|c|}
\hline & \% & trend $\star *$ \\
\hline $\begin{array}{l}30 \text { jaar } \\
30-49 \text { jaar } \\
50-59 \text { jaar } \\
60-64 \text { jaar }\end{array}$ & $\begin{array}{r}26 \\
59 \\
11 \\
\#\end{array}$ & $\begin{array}{r}-- \\
+ \\
++\end{array}$ \\
\hline
\end{tabular}

III. Aandeel opleidingscategorieën:

(gemiddeld percentage 1979 - 1985*)

\begin{tabular}{|c|c|c|}
\hline & $\underline{\%}$ & trend $* *$ \\
\hline Universitair opgeleiden & $\#$ & \\
\hline HBO-ers & 36 & 0 \\
\hline MBO-ers & 32 & 0 \\
\hline $\begin{array}{l}\text { LBO-ers } \\
\text { HAVO/VWO-ers }\end{array}$ & $\begin{array}{r}10 \\
\#\end{array}$ & + \\
\hline MAVO-ers & 7 & 0 \\
\hline Bas is onderwijs & 6 & - \\
\hline
\end{tabular}

IV. Belangrijkste bedrijfsklassen waarin men werkzaam is: (gemiddeld percentage 1979 - 1985*)
1. (14-19) Commerciële diensten w.v. (15) Handel
2. (20-22) Kwartaire sector
3. (2-12) Industrie en openbare $\begin{array}{ll} & \text { nutsbedrijuen } \\ \text { w.v. } & \text { (5) Papier- en grafische } \\ \text { industrie }\end{array}$

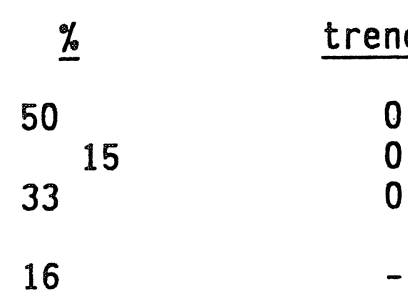




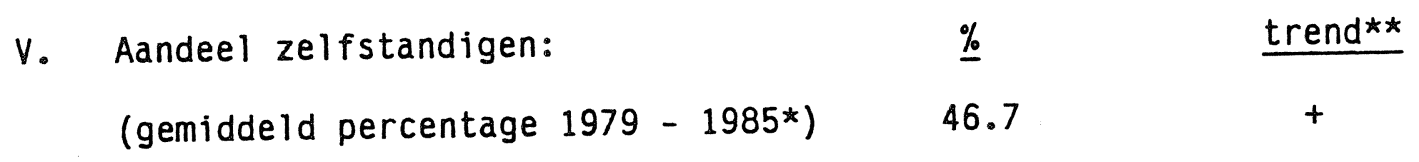

INDICATOREN

Vervangingsbehoefte ouderen

- Gemiddelde van 1979-1985*:

Absorptiegraad $<30$ jarigen

- Gemiddelde van 1979-1985*:

Branchespreiding

- Gemiddelde van 1979 - 1985*:

Conjunctuurgevoeligheid

- Periode 1950 - 1985:

\section{PROGNOSES}

Arbeidsmarktontwikkeling 1985 - 1992:

(in \% van werkgelegenheid in 1985)

Werkgel egenheidsontwikkeling

Vervangingsuraag

Totale vraag naar nieuwkomers

Vraag naar schoolverlaters indicator kwalifi- trend **

catie

1.06 gemiddeld +

$0.80 \quad k l e i n$

0.84 groot

0

$11.1 \%$ gemiddeld

\section{TYPERING}

Redelijk werkgelegenheidsperspectief, weinig conjunctuurgevoelig en er zijn ook goede uitwijkmogelijkheden. 
DIVERSE WETENSCHAPPELIJKE E.A. VAKSPECIALISTEN

Code: 19

HISTORISCHE DATA

trend $* *$

I. Gemiddeld aantal werkenden 1979-1985*: 97.900

Gemiddeld \% van het totaal aantal

werkenden 1979 - 1985*:

1.94

$++$

Gemiddeld aantal werkenden 1979 - 1985* in enkele

specifieke beroepsgroepen:

- Sociologen, psychologen e.a. sociale wetenschapsbeoefenaren (code 192):

- gemiddeld \% van het totaal aantal werkenden:

19.500

0.39

$++$

- Taalkundigen, vertalers, tolken

(code 195):

4.300

- gemiddeld \% van het totaal aantal werkenden:

0.08

$+$

II. Aandeel leeftijdgroepen:

(gemiddeld percentage 1979 - 1985*)

$<30$ jaar

$\underline{\%}$

$\underline{\text { trend } * *}$

30 - 49 jaar

50 - 59 jaar

60 - 64 jaar

30

57

11

$+$

$+$

III. Aandeel opleidingscategorieën:

(gemiddeld percentage 1979 - 1985*)

$\underline{\%}$

trend **

Universitair opgeleiden

25

HBO-ers

MBO-ers

LBO-ers

HAVO/VWO-ers

MAVO-ers

Basis onderwijs

43
19
$\#$
5
$\#$
$\#$ 
IV. Belangrijkste bedrijfsklassen waarin men werkzaam is: (gemiddeld percentage 1979 - 1985*)

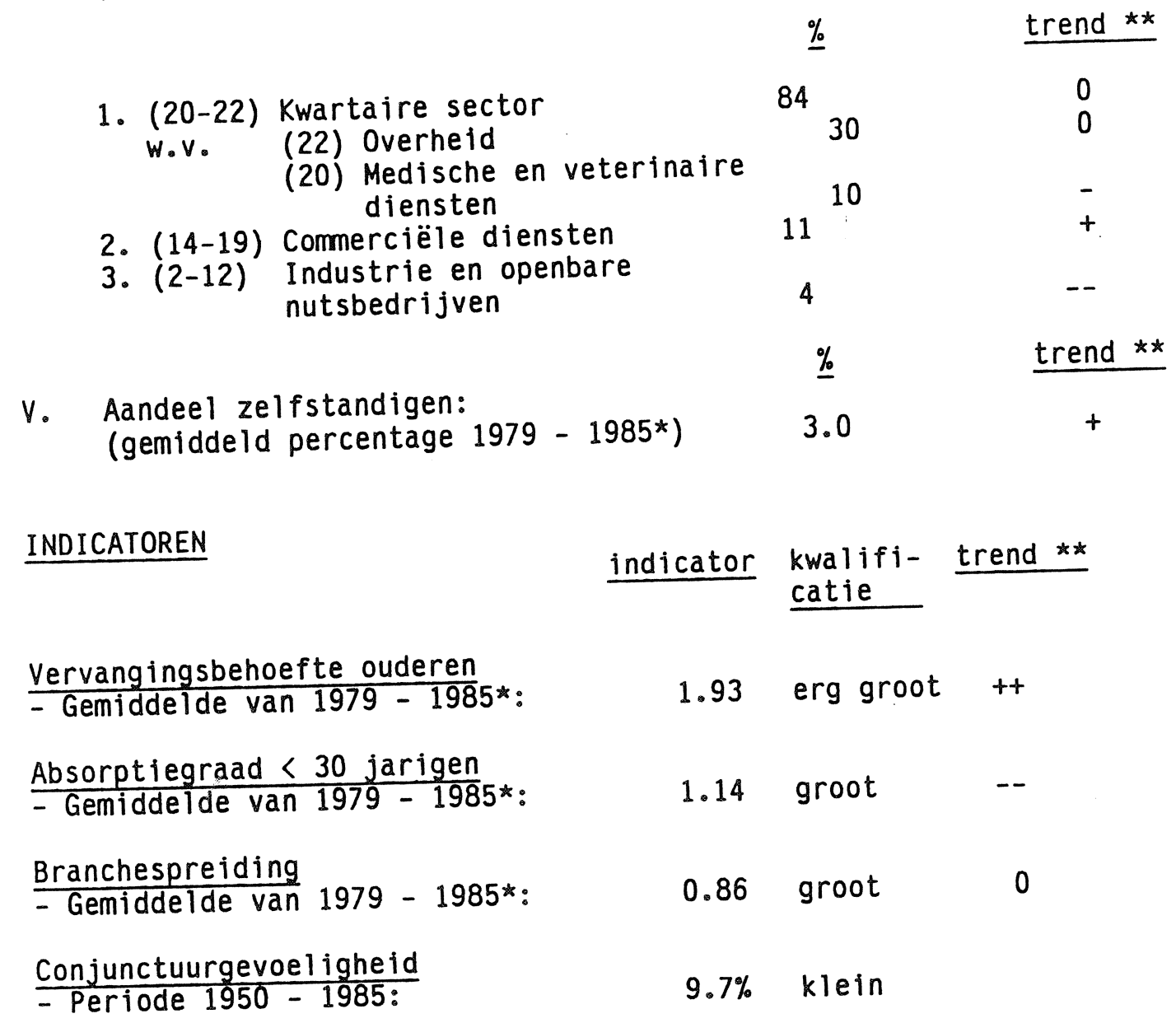

\section{PROGNOSES}

Arbeidsmarktontwikkeling 1985 - 1992:

(in \% van werkgelegenheid in 1985)

\%

10 gemiddeld

Werkgelegenheidsontwikkeling

Vervangingsuraag

Totale vraag naar nieuwkomers

Vraag naar schoolverlaters
9 erg laag

$\overline{19} \quad$ laag

0 nihil

\section{TYPERING}

Matig werkgelegenheidsperspectief, weinig conjunctuurgevoelig, en er zijn ook goede uitwijkmogelijkheden. 
BELEIDVOERENDE EN HOGERE LEIDINGGEVENDE FUNCTIES BIJ OPENBAAR BESTUUR

Code: 20

HISTORISCHE DATA

trend $\star \star$

I. Gemiddeld aantal werkenden 1979-1985*: 4.300

Gemiddeld \% van het totaal aantal

werkenden 1979 - 1985*:

0.09

$+$

Gemiddeld aantal werkenden 1979 - 1985* in enkele specifieke beroepsgroepen.

- Beleidvoerende en leidinggevende hoofdambtenaren bij openbaar bestuur (code 202):

- gemiddeld \% van het totaal aantal werkenden:

II. Aandeel leeftijdgroepen:

(gemiddeld percentage 1979 - 1985*)

$$
\begin{aligned}
& 30 \text { jaar } \\
& 30-49 \text { jaar } \\
& 50-59 \text { jaar } \\
& 60-64 \text { jaar }
\end{aligned}
$$

III. Aandeel opleidingscategorieën:

(gemiddeld percentage 1979 - 1985*)

Universitair opgeleiden

41

$\mathrm{HBO}$-ers

MBO-ers

LBO-ers

HAVO/VWO-ers

MAVO-ers

Basis onderwijs

28

\#

\#

节

$\#$ 
IV. Belangrijkste bedrijfsklassen waarin men werkzaam is: (gemiddeld percentage 1979 - 1985*)
1. (20-22) Kwartaire sector W.V. (22) Overheid
\% $\quad$ trend $\star *$
$9896 \quad 0$

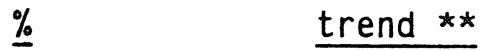
V. Aandeel zelfstandigen:
(gemiddeld percentage $1979-1985^{\star}$ ) $1.2+$

\section{INDICATOREN}

Vervangingsbehoefte ouderen

- Gemiddelde van 1979-1985*: 4.81 erg groot ++

Absorptiegraad $<30$ jarigen

- Gemiddelde van 1979-1985*: $\quad 0.10$ erg klein ++

Branchespreiding

- Gemiddelde van 1979 - 1985*: 0.09 klein +

Conjunctuurgevoeligheid

- Periode 1950 - 1985:

$4.5 \%$ erg klein

\section{PROGNOSES}

Arbeidsmarktontwikkeling 1985 - 1992:

(in \% van werkgelegenheid in 1985)

Werkge legenheidsontwikkel ing

Vervangingsvraag

indicator kwalifi- trend **

catie

Totale vraag naar nieuwkomers

\% kwalificatie

Vraag naar schoolverlaters

14 hoog

$\frac{28}{43} \quad$ erg hoog

$\frac{28}{43} \quad$ erg hoog

$0 \quad$ ninil

TYPERING

Goed werkgelegenheidsperspectief, weinig conjunctuurgevoelig, maar er zijn ook weinig uitwijkmogelijkheden. 
BELEIDVOERENDE EN HOGERE LEIDINGGEVENDE FUNCTIES (EXCLUSIEF OPENBAAR BESTUUR)

Code: 21

HISTORISCHE DATA

I. Gemiddeld aantal werkenden 1979-1985*: 142.400

trend $\star \star$

Gemiddeld \% van het totaal aantal

werkenden 1979 - 1985*:

2.82

$++$

II. Aandeel leeftijdgroepen:

(gemiddeld percentage 1979 - 1985*)

$$
\begin{array}{ll}
30 & \text { jaar } \\
30-49 & \text { jaar } \\
50-59 & \text { jaar } \\
60-64 & \text { jaar }
\end{array}
$$

6

63

25

trend **

III. Aandeel opleidingscategorieën:

(gemiddeld percentage 1979 - 1985*)

Universitair opgeleiden

trend $* *$

HBO-ers

MBO-ers

LBO-ers

HAVO/VWO-ers

MAVO-ers

Basis onderwijs

12
25
37
8
6
$\#$
5

0

$-$

$+$

$+$

$8-$


IV. Belangrijkste bedrijfsklassen waarin men werkzaam is: (gemiddeld percentage 1979 - 1985*) nutsbedrijven

1. (2-12) Industrie en openbare w.v. (7/8) Basismetaal, metaalprodukten- en optische industrie

2. (14-19) Commerciële diensten $w \cdot v$.
(17) Overige transport
opslag- en commun catiebedrijuen

3. (13) Bouwnijuerheid

4. (20-22) Kwartaire sector

5. (1) Landbouw, bosbouw en visserij

V. Aandeel zelfstandigen:

(gemiddeld percentage $1979-1985^{\star}$ ) $\underline{\%}$

35

trend $* *$

0

$\begin{array}{lll} & 8 & 0\end{array}$

$\begin{array}{rrr} & 7 & ++ \\ 16 & & 0 \\ 15 & & -\end{array}$

\%

trend $* *$

18.4

\section{INDICATOREN}

Vervangingsbehoefte ouderen

- Gemiddelde van 1979 - 1985*:

Absorptiegraad < 30 jarigen

- Gemiddelde van 1979 - 1985*:

Branchespreiding

- Gemiddelde van 1979 - 1985*:

Conjunctuurgevoeligheid

- Periode 1950 - 1985:

$\begin{array}{ccc}\text { indicator } & \begin{array}{l}\text { kwalifi- } \\ \text { catie }\end{array} & \text { trend ** } \\ 2.48 & \text { erg groot }++ \\ 0.23 & \text { erg klein } & -- \\ 0.98 & \text { groot } & 0\end{array}$

$14.8 \%$ gemiddeld 
PROGNOSES

Arbeidsmarktontwikkeling 1985 - 1992:

(in \% van werkgelegenheid in 1985)

Werkgelegenheidsontwikkeling

\% kwalificatie

Vervangingsvraag

Totale vraag naar nieuwkomers

7 laag

$\frac{12}{19} \quad$ laag

$\frac{12}{19} \quad$ laag

Vraag naar schoolverlaters

$0 \quad$ nihil

TYPERING

Matig werkgelegenheidsperspectief, weinig conjunctuurgevoelig en er zijn ook goede uitwijkmogelijkheden. 


\section{UITVOERENDE HOOFDAMBTENAREN}

Code: 31

HISTORISCHE DATA

trend $* *$

I. Gemiddeld aantal werkenden 1979-1985*: 18.200

Gemiddeld \% van het totaal aantal

werkenden 1979 - 1985*: 0.36

II. Aandeel leeftijdgroepen:

(gemiddeld percentage 1979 - 1985*)

\begin{tabular}{lrc} 
& \multicolumn{1}{c}{$\%$} & trend $\star \star$ \\
\hline 30 jaar & 7 & - \\
$30-49$ jaar & 60 & + \\
$50-59$ jaar & 28 & - \\
$60-64$ jaar & 6 & +
\end{tabular}

III. Aandeel opleidingscategorieën

(gemiddeld percentage 1979 - 1985*)

\begin{tabular}{lcc} 
& $\underline{6}$ & trend ** \\
\cline { 2 - 3 } Universitair opgeleiden & 26 & + \\
HBO-ers & 34 & 0 \\
MBO-ers & 30 & 0 \\
LBO-ers & $\#$ & \\
HAVO/VWO-ers & $\#$ & \\
MAVO-ers & $\#$ & \\
Basis onderwijs & $\#$ &
\end{tabular}

IV. Belangrijkste bedrijfsklassen waarin men werkzaam is:

(gemiddeld percentage 1979 - 1985*)

\begin{tabular}{|c|c|c|c|}
\hline & & $\%$ & trend $\star *$ \\
\hline $\begin{array}{l}\text { 1. }(20-22) \\
\text { w.V. } \\
\text { 2. }(14-19) \\
\text { 3. }(2-12)\end{array}$ & $\begin{array}{l}\text { Kwartaire sector } \\
\text { (22) Overheid } \\
\text { Commerciële diensten } \\
\text { Industrie en openbare } \\
\text { nutsbedrijven }\end{array}$ & ${ }_{\#}^{94} 91$ & $\begin{array}{l}0 \\
+\end{array}$ \\
\hline $\begin{array}{l}\text { Aandeel zel } \\
\text { (gemiddeld }\end{array}$ & $\begin{array}{l}\text { Ifstandigen: } \\
\left.\text { percentage } 1979-1985^{\star}\right)\end{array}$ & $\underline{\%}$ & \\
\hline
\end{tabular}


INDICATOREN

Vervangingsbehoefte ouderen

indicator kwalifi- trend ** catie

- Gemiddelde van 1979 - 1985*

3.07 erg groot -

Absorptiegraad $<30$ jarigen

- Gemiddelde van 1979 - 1985*:

0.26 erg klein --

Branchespreiding

- Gemiddelde van 1979 - 1985*

0.19 klein

Conjunctuurgevoeligheid

- Periode 1950 - 1985:

$4.2 \%$ erg klein

\section{PROGNOSES}

Arbeidsmarktontwikkeling 1985 - 1992:

(in \% van werkgelegenheid in 1985)

Werkgelegenheidsontwikkeling

Vervangingsuraag

Totale vraag naar nieuwkomers

\% $\quad$ kwalificatie

Vraag naar schoolverlaters

25 erg hoog

22 hoog

$\frac{22}{47} \quad$ erg hoog

41 erg hoog

\section{TYPERING}

Goed werkgelegenheidsperspectief, weinig conjunctuurgevoelig maar er zijn ook weinig uitwijkmogelijkheden. 
SECRETARESSEN, TYPISTEN E.D.

Code: 32

HISTORISCHE DATA

trend **

I. Gemiddeld aantal werkenden 1979-1985*: 139.200

Gemiddeld \% van het totaal aantal

werkenden 1979 - 1985*:

2.76

0

II. Aandeel leeftijdgroepen:

(gemiddeld percentage 1979 - 1985*)

$$
\begin{aligned}
& 30 \text { jaar } \\
& 30-49 \text { jaar } \\
& 50-59 \text { jaar } \\
& 60-64 \text { jaar }
\end{aligned}
$$

III. Aandeel opleidingscategorieën:

(gemiddeld percentage 1979 - 1985*)

Universitair opgeleiden

$\mathrm{HBO}$-ers

MBO-ers

LBO-ers

HAVO/VWO-ers

$\#$

MAVO-ers

Basis onderwijs 
IV. Belangrijkste bedrijfsklassen waarin men werkzaam is: (gemiddeld percentage 1979 - 1985*)

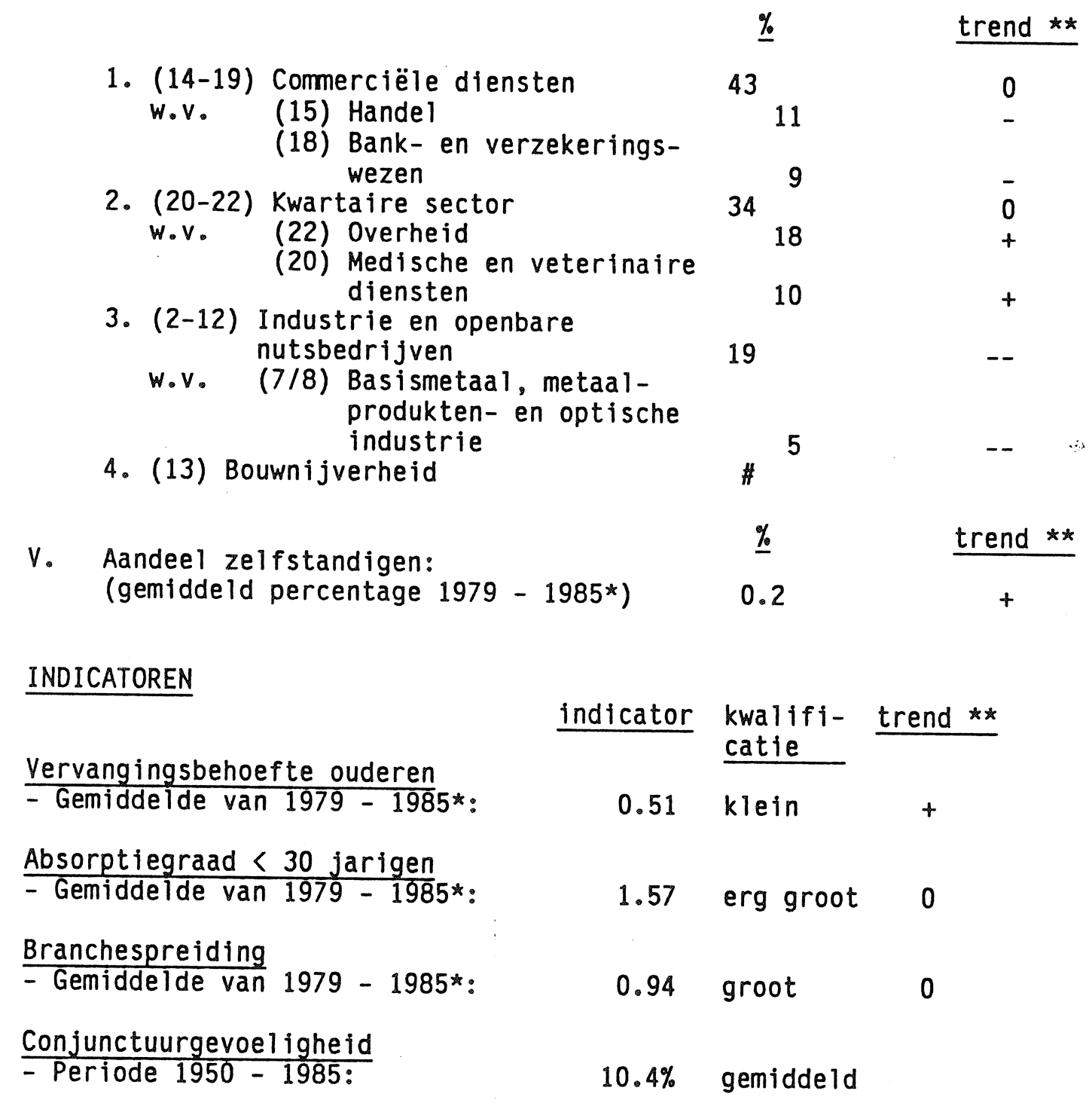




\section{PROGNOSES}

Arbeidsmarktontwikkeling 1985 - 1992:

(in \% van werkgelegenheid in 1985)

\% $\quad$ kwalificatie

Werkgelegenheidsontwikkeling

14 hoog

Vervangingsvraag

22 hoog

Totale vraag naar nieuwkomers

35 hoog

Vraag naar schoolverlaters

30

erg hoog

\section{TYPER ING}

Goed werkgelegenheidsperspectief, weinig conjunctuurgevoelig, er zijn ook goede uitwijkmogelijkheden. 
BANKEMPLOYÉS, LOKETTISTEN E.D.

Code: 33

HISTORISCHE DATA

trend $* *$

I. Gemiddeld aantal werkenden 1979-1985*: 279.600 Gemiddeld \% van het totaal aantal werkenden 1979 - 1985*:

II. Aandeel leeftijdgroepen:

(gemiddeld percentage 1979 - 1985*)

$<30$ jaar

30 - 49 jaar

50 - 59 jaar

60 - 64 jaar

III. Aandeel opleidingscategorieën:

(gemiddeld percentage 1979 - 1985*)
\%

47

39

11

trend $\star *$

0

$+$

$-$

trend $* *$

$\underline{\%}$

$\#$

6

41
14

11

17

6

MAVO-ers

Basis onderwijs 
IV. Belangrijkste bedrijfsklassen waarin men werkzaam is:

(gemiddeld percentage 1979 - 1985*)
1. (14-19) Commerciële diensten W.V. (18) Bank- en verzekerings- wezen
(15) Hande 1
(17) Overige transport-, opslag en communicatie-

2. (20-22) Kwartaire sector $\begin{array}{ll}(20-22) & \text { Kwartaire secto } \\ \text { w.v. } & \text { (22) Overheid }\end{array}$

3. (2-12) Industrie en openbare

nutsbedrijven

4. (13) Bouwnijverheid

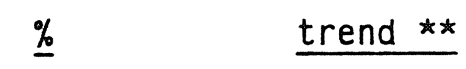

640

0

$27 \quad 0$

$18+$

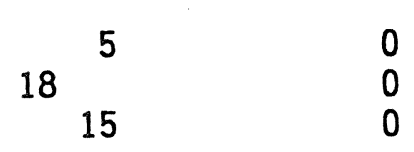

12

$\#$

\% trend $* *$

v. Aandeel zelfstandigen:

(gemiddeld percentage $1979-1985^{*}$ ) 0.8

\section{INDICATOREN}

Vervangingsbehoefte ouderen

- Gemiddelde van 1979-1985*:

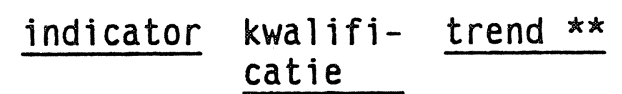

Absorptiegraad $<30$ jarigen

- Gemiddelde van 1979-1985*:

1.12 groot

1.25 groot 0

Branchespreiding

- Gemiddelde van 1979 - 1985*:

0.90 groot 0

Conjunctuurgevoeligheid

- Periode 1950 - 1985:

$10.0 \% \quad$ gemiddeld 


\section{PROGNOSES}

Arbeidsmarktontwikkeling 1985 - 1992:

(in $\%$ van werkgelegenheid in 1985)

$\begin{array}{lcl} & \% & \text { kwalificatie } \\ \text { Werkgelegenheidsontwikkeling } & 12 & \text { hoog } \\ \text { Vervangingsvraag } & 16 & \text { laag } \\ \text { Totale vraag naar nieuwkomers } & 28 & \text { gemiddeld } \\ \text { Vraag naar schoolverlaters } & 24 & \text { hoog } \\ \text { TYPERING } & & \end{array}$

Redelijk werkgelegenheidsperspectief, weinig conjunctuurgevoelig en er zijn ook goede uitwijkmogelijkheden. 


\section{DIVERSE ADMINISTRATIEVE FUNCTIES}

Code: 39

HISTORISCHE DATA

trend $* *$

I. Gemiddeld aantal werkenden 1979-1985*: 388.400

Gemiddeld \% van het totaal aantal

werkenden 1979 - 1985*:

7.7

0

II. Aandeel leeftijdgroepen:

(gemiddeld percentage 1979 - 1985*)

$$
\begin{aligned}
& 30 \text { jaar } \\
& 30-49 \text { jaar } \\
& 50-59 \text { jaar } \\
& 60-64 \text { jaar }
\end{aligned}
$$

III. Aandeel opleidingscategorieën:

(gemiddeld percentage 1979 - 1985*)

Universitair opgeleiden

$\mathrm{HBO}$-ers

MBO-ers

LBO-ers

HAVO/VWO-ers

MAVO-ers

Basis onderwijs 
IV. Belangrijkste bedrijfsklassen waarin men werkzaam is: (gemiddeld percentage $1979-1985^{\star}$ )

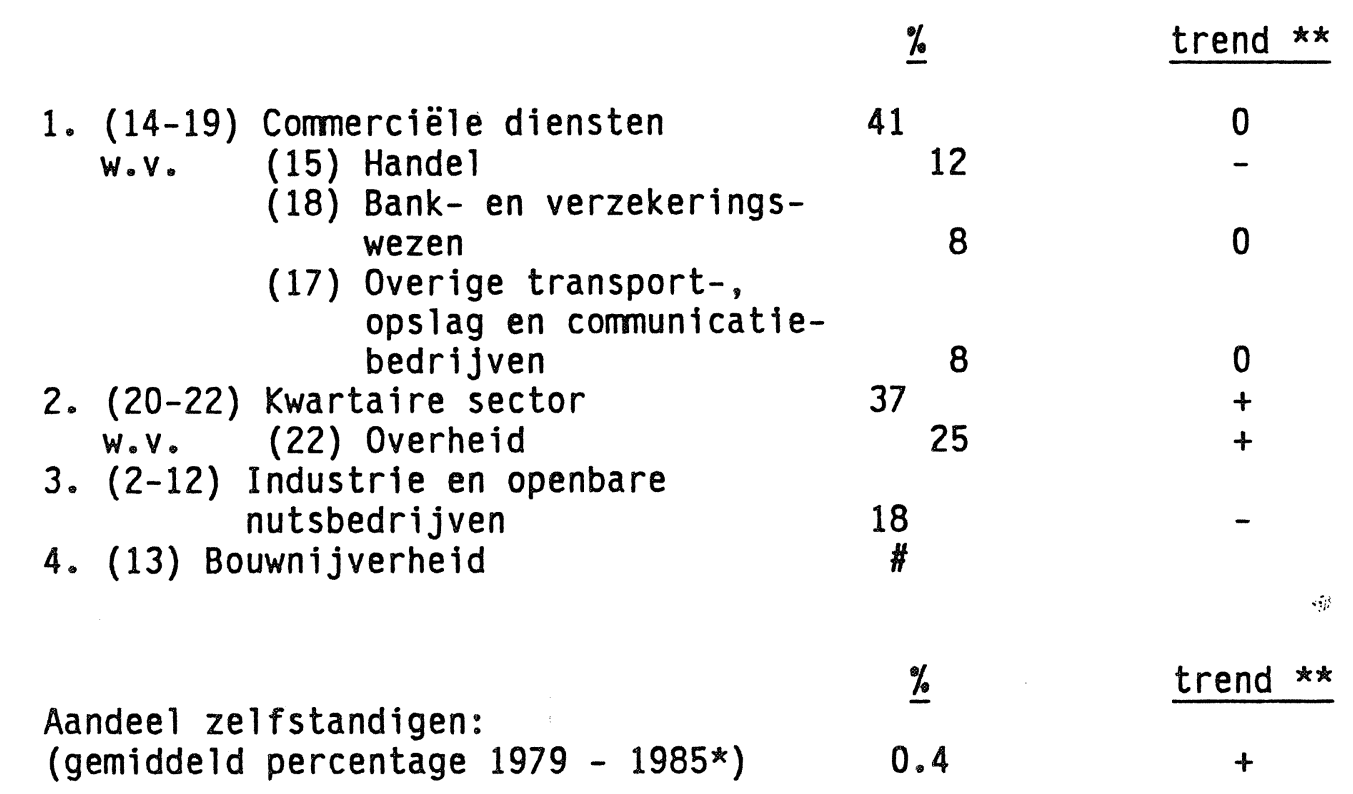

\section{INDICATOREN}

Vervangingsbehoefte ouderen

$\frac{\text { indicator }}{1.18} \frac{\begin{array}{l}\text { kwalifi- } \\ \text { catie }\end{array}}{\text { groot }}$ trend **

- Gemiddelde van 1979-1985*

1.18 groot

Absorptiegraad $<30$ jarigen

- Gemiddelde van 1979-1985*.

1.17 groot 0

Branchespreiding

- Gemiddelde van 1979 - 1985*:

0.94 groot $\quad+$

Conjunctuurgevoeligheid

- Periode 1950 - 1985:

$9.8 \% \quad k l e i n$ 
PROGNOSES

Arbeidsmarktontwikkeling 1985 - 1992:

(in \% van werkgelegenheid in 1985)

Werkgel egenheidsontwikkeling

Vervangingsuraag

Totale vraag naar nieuwkomers

\%

kwalificatie

Vraag naar schoolverlaters

9 gemiddeld

16 laag

$\overline{25}$ gemiddeld

21 hoog

\section{TYPERING}

Redelijk werkgelegenheidsperspectief, weinig conjunctuurgevoelig en er zijn ook goede uitwijkmogelijkheden. 
BIJLAGE III: OVERZICHT PUBLICATIES DEELMARKTEN

Bron: ROA 


\section{LETTEREN}

Doeksen, H.J. en Leo Jansen: Buiten verwachting?!, Beroepen van Neerlandici afgestudeerd te Utrecht in de jaren 1978-1985 en de arbeidsmarkt, RU Utrecht, 1986.

AGRARISCHE WETENSCHAPPEN (EN HUISHOUDKUNDE)

Stichting Maatschappelijke Plaats Wageningse Afgestudeerden \& NILI, loopbaan enquête 1983, deel I \& II, Wageningen, 1985.

\section{WIS- EN NATUURKUNDE}

Lingeman, E.W.A; De Nederlandse Natuurkundigen, Onderzoek naar werkgelegenheid. Nederlandse Natuurkundigen Vereniging, Commissie Werkgelegenheid voor Fysici, 1984 .

Koninklijke Nederlandse Chemische Vereniging- Commissie Arbeidsmarkt Chemici: Resultaten negende vacature-enquête Arbeidsmarktprognose 1986/1987, september 1986.

Kwantes, P.M. en J.W. Engbers: Opleiding en bestemming van biofysici 19831984. Koninklijke Nederlandse Akademie van Wetenschappen, Commissie voor de Biochemie en de Biofysica, januari 1987.

Kwantes, P.M. en J.W. Engbers: Arbeldsmarkt voor biochemici 1984-1985, Koninklijke Nederlandse Akademie van Wetenschappen, Commissie voor de Biochemie en de Biofysica, december 1986.

Linde, drs. P. van der e.a.: De vraag naar biologen. Een onderzoek onder werkgevers. NIBI Arbeidsmarktonderzoek 1, Utrecht 1984.

Tichelaar, M.: Biologen en Biologieleraren op de arbeidsmarkt: resultaten van een enquête onder afgestudeerden aan de universiteiten, NIBIArbeidsmarktonderzoek 4, Utrecht 1987.

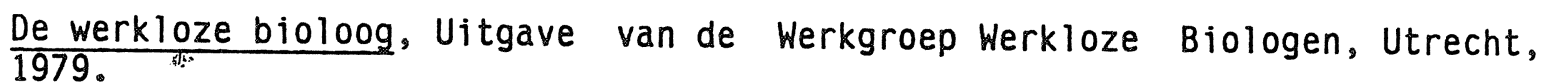

\section{TECHNISCHE WETENSCHAPPEN}

Bouman, J. e.a., Middelgrote en dienstverlenende bedrijven vragen ir's, De ingenieur, $n r .6$ (juni 1987), p. 11-15. (Verslag van de achtste WAIenquête).

Kwartaaloverzicht van werkloosheid van ingenieurs en overige academici, maart 1988, Afdeling Onderwijs en Onderzoek, TU Delft.

\section{MEDISCHE OPLEIDINGEN}

Broek, R.J.A.M., Arbeidsaanbod en arbeidsvraag in de gezondheidszorg op lange termijn, Economisch Statistische Berichten, 5 december 1984, p. 11491151. 
Bruers, J. en drs. G. van Rossum; Werkzoekende tandartsen, In: Nederlands Tandartsenblad, 1987, $\mathrm{nr}$. 16, p. 454-455.

Centraal Planbureau/Sociaal Cultureel Planbureau, Arbeidsvraag en arbeidsaanbod in de gezondheidszorg op lange $\frac{\text { termijn, Project }}{\text { personeelsworis }}$ personeelsvoorziening kwartaire sector, Bulletin no 5, juni 1984.

Eindrapport van de Adviescomissie Opleiding Tandarts, november 1985.

Hogewind F.J. De ontwikkeling van het aantal arbeidsplaatsen in de internationale gezondheidszorg 1970-1990, Nationaal Ziekenhuis Instituut, juni 1982, no. 82.304

Jaspers, Fr. C.A. en E. L. Vrijland (red.), Medische specialisten: vraag en aanbod, Bohn, Scheltema en Holkma, Utrecht/Antwerpen, 1983.

Nederlands Instituut van de Eerste Lijnsgezondheidszorg (NIVEL), Utrecht:

- Cijfers uit de registratie van beroepen in de eerste-lijnsgezoritheidszorg, 1987

- Registratie adspirant huisartsen, peiling 1987.

Passenier, J., Verzorgers in opmars, Economisch Statistische Berichten, 671 (1982), p. 432-445.

Koninklijke Nederlandse Maatschappij voor Diergeneeskunde, Jaarboek 1987, p. $336-342$.

Visser, L. Arbeidsmarktverkenning gezondheidszorg, Ministerie van Sociale Zaken en Werkgelegenheid, DG Arbvo, z.j., p. 95-96.

Walta, H.F., Ontwikkelingen in het aanbod van en de behoefte aan medische specialisten, Medisch Contact, no. 45, 1980, p. 1393-1399.

PHARMACIE

Eekhoff, R.M.W.: Farmaceutisch jaaroverzicht 1986 in cijfers, In: Pharmaceutisch Weekblad (122), 1987, p. 715-720.

SOCIAAL CULTURELE WETENSCHAPPEN

Cremers, W.J.G. en Th. J. IJzerman, De beroepsperspectieven voor sociologen, (60) 1985, nr 1, Mens \& Maatschappij, p. 79-90.

Rodenhuis, $W_{0}:$ Jonge politicologen aan het woord over opleiding en werkkring, Acta Politica, 1987, p. 327-346.

Heide, Hugo P. de; Politicologen aan het werk; Een bespreking van de resultaten van een enquête onder afgestudeerde politicologen van de UVA. Subfaculteit der Algemene Politieke en Sociale Wetenschappen, zomer ' 82.

"Is er toekomst voor psychologen?", De Psycholoog (14) 1984, no. 6, p. 257266.

MO-B AKTEN

Broeder, G. den; en J. de Voogd: De Arbeidsmarkt voor leerkrachten in het voortgezet onderwijs. Economisch Statistische Berichten (71), 10 december $1986, \mathrm{nr} .3585, \mathrm{p} .1218-1221,1228$. 
BIJLAGE IV: DATA-FILE TEN BEHOEVE VAN UPDATING ARBEIDSMARKTINFORMATIE

Bron: ROA 
RECORD STUDIERICHTING

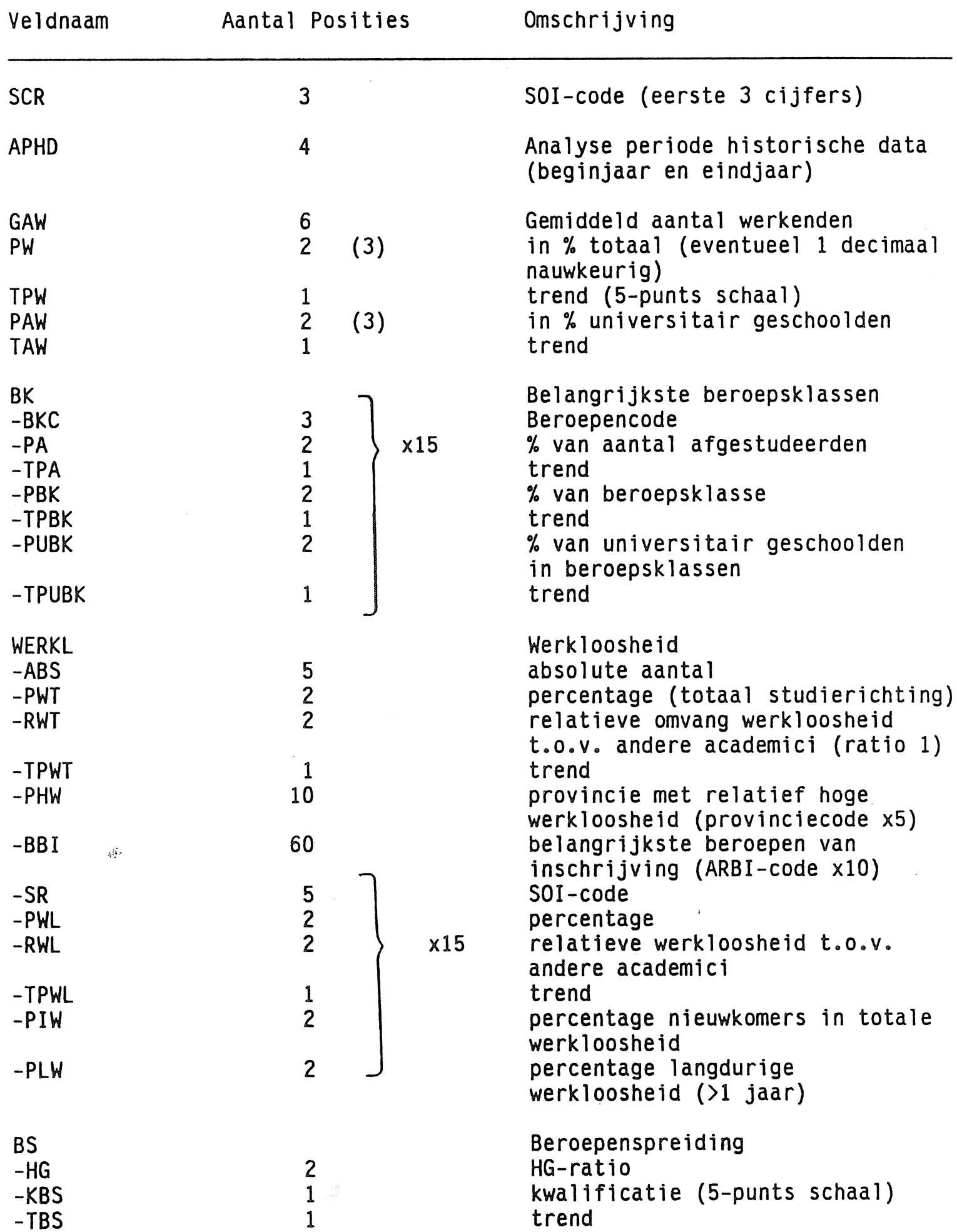


PROGN

$$
-P P
$$

$-W O$

-KWO

$-V V$

$-K V V$

-TV

-KTV

-IA

$-K J A$

-IAM

$-K I A M$
4

3

1

2

1

2

1

2

1

2

1
Prognoses

prognoseperiode (begin en eindjaar) werkgelegenheidsontwikkeling

$(\%$ en + of -$)$

kwalificatie (5-punts schaal)

vervangingsuraag $(\%)$

kwalificatie (5-punts schaal)

totale vraag naar nieuwkomers

kwalificatie (5-punts schaal)

instroom afstuderenden

kwalificatie (5-punts schaal)

indicator arbeidsmarktsituatie

prognosejaar

kwalificatie (5-punts schaal) 
RECORD BEROEPSKLASSEN

Veldnaam Aantal posities Omschrijuing

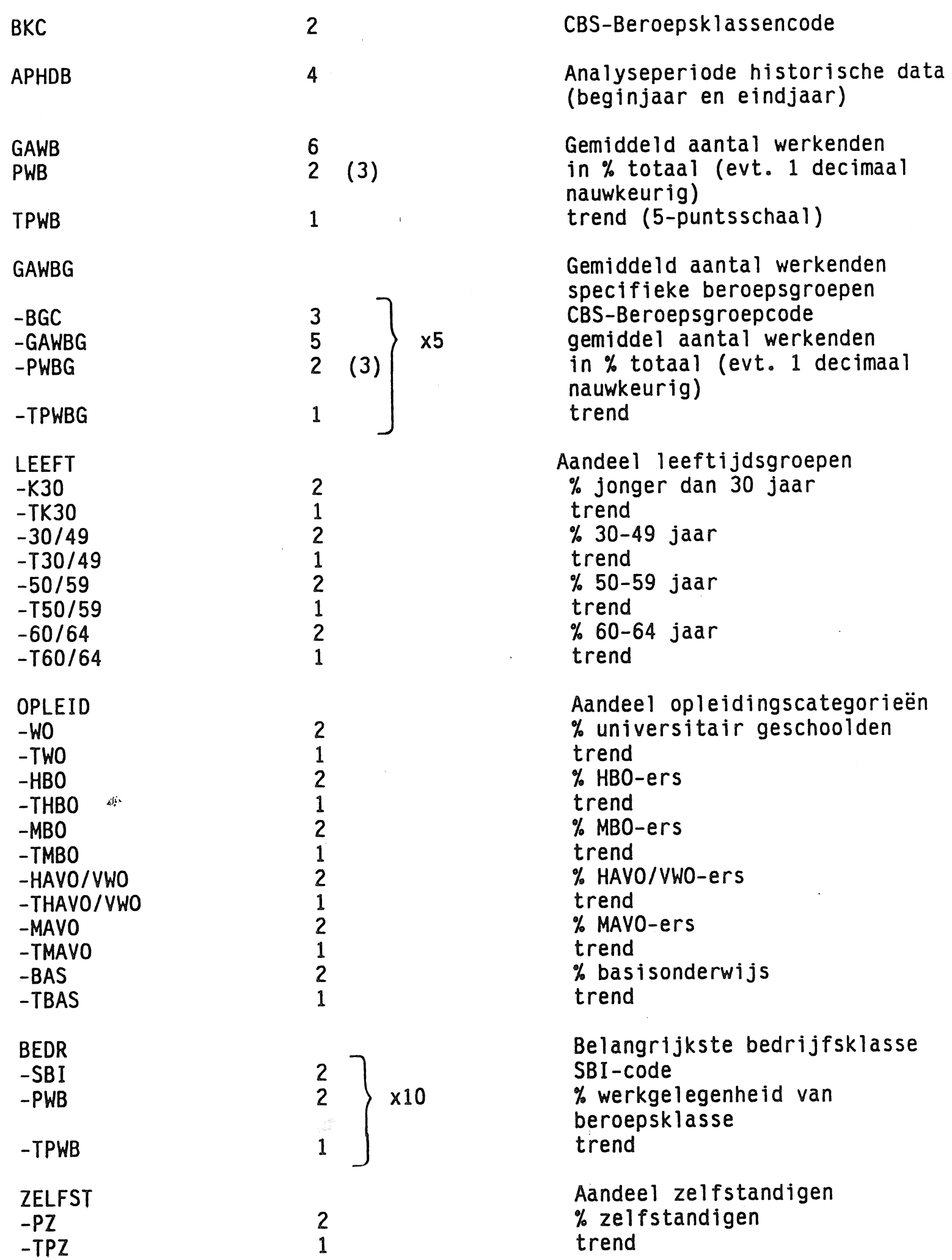


VERV

-IV

$-K V$

$-T V$

ABS

$-I A J$

-KIAJ

$-T I A J$

BRAS

-IBS

$-K B S$

$-T B S$

CONJ

-ICG

$-K C G$

PROGN

$-P P B$

$-W O B$

$-K W O B$

$-V V B$

$-K V V B$

$-V S B$

$-K V S B$
2

1

4

3

3

1

1

3

1

1

2

1

1

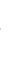

4

1

2

1

2

1
Vervangingsbehoefte ouderen

indicator

kwalificatie

(5-punts schaal)

trend

Absorptiegraad jongeren

indicator

kwalificatie

trend

Branchespreiding

indicator

kwalificatie

trend

Conjunctuurgevoel igheid indicator $(\%)$

kwalificatie

Prognoses

prognoseperiode (begin

en eindjaar)

werkgelegenheidsontwik-

keling $(\%$ en + of -$)$

kwalificatie

vervangingsvraag

kwalificatie

vraag naar schoolverlaters kwalificatie 